\title{
EL PODER TUTELADOR DE LA JUSTICIA Y EL JUEZ COMO PODER INDEPENDIENTE
}

\author{
Isidoro Alvarez Sacristán \\ Doctor en Derecho. \\ Magistrado.
}

Sumario: I. El poder tutelador de la justicia. 1. Introducción. 2. ¿Es poder el poder judicial? 3. El mandato tutelador del artículo 24 de la C.E. 4. El papel mediador del Juez. 5. El elemento personal de la tutela judicial. 6. La tutela ordinaria y el amparo. 7. El derecho a un proceso justo. II. El Juez como poder independiente. 1. Antecedentes. 2. La independencia como término difuso. 3. El sometimiento a la Ley. 4. Independencia e interpretación. La contaminación política. 5. La independencia sociológica. 6. La independencia orgánica. 7. La independencia extrajudicial. 8. La responsabilidad.

\section{EL PODER TUTELADOR DE LA JUSTICIA}

\section{Introducción}

Una fuente de la Carta Magna española obliga a los juzgadores a otorgar (y a todos a obtener) la tutela judicial efectiva (art. 24 CE). Tal derecho fundamental, que tiene una naturaleza constitutiva, tiene múltiples posibilidades de ejercerse. Bien sea a través de la acción legitimatoria de los particulares —elemento personal—, bien por medio de los procesos correspondientes - elemento instrumental-o por medio, siempre, de la acción del Juez —elemento jurisdiccional—.

A través de los jueces es por el único cauce por el que se obtiene la tutela efectiva. Si bien el poder ejecutivo debe cumplir los derechos fundamentales que la norma superior ampara, como mandato a que se refiere el artículo 9.1 CE y que ordena a los «poderes públicos» observar la Constitución, lo cierto es que quien se siente perturbado en su derecho tiene un único medio tutelador a través del cauce jurisdiccional. Se convierte al Juez, así, en guardián de la norma y cuyo compro- 
miso de juzgar y hacer ejecutar lo juzgado alcance caracteres subliminales para adentrarse en otro mundo que es tangencial con el Derecho. Estamos refiriéndonos a la ética, a la deontología, el arte de juzgar, a la equidad. Todas las virtudes $-\mathrm{u}$ obligaciones morales- que no son cuestiones estrictamente técnico-jurídicas.

Un Juez tutelador entremezclado en los avatares sociológicos de la caridad o la misericordia no le permite la objetividad de la efectividad de la norma. Por el contrario un Juez inquisidor, que vaya más allá del rigor de la ley, que no juzgue con las normas interpretativas, que se olvide de la equidad, y que encorsete el brocardo sic lex sic iudex, puede tergiversar el principio de la efectividad. Porque tal expresión no se termina en el simple acceso a la jurisdicción, sino que va más allá de la actuación burocrática de los Tribunales. No sólo la tutela se refiere al derecho de la prueba, a las dilaciones indebidas, a la posibilidad de que otro Tribunal pueda ver el litigio, sino que la efectividad exige que el poder esté signado por el halo de lo que se ha llamado — tildado de anacrónico, es verdad- el «arte de juzgar», al que se refiere Entrena Klett $^{1}$, considerando que «1a cualidad que los ha transformado de meros técnicos (a los jueces) en artistas del Derecho ha sido su sentido de lo justo, la equidad». No es una norma que se hubiera sustantivizado en las Leyes de una manera clara (en algunas sí se especifica, como por ejemplo en el arículo 106 de la Ley 30/1992 de 26 de noviembre), sino que se encuentra en los supuestos del artículo 3 del CC, que debe aplicarse ponderadamente cuando se interpreten las normas, sin que se «descanse» en ella de una forma exclusiva. El peligro de la equidad no está en que se sea más o menos rígido o flexible sino en el peligro de que se subjetivice de tal manera que se planteen y resuelvan de distinta forma litigios sustancialmente iguales, sobre la base del talante del juzgador. La justicia así aplicada ya no es efectiva, sino discriminatoria y arbitraria. La equidad no es una fuente del Derecho - para su aplicación pura está el arbitraje privado - sino que se configura como un criterio de interpretación de una manera «ponderada» (consideración imparcial) en concurrencia con otros factores y nunca, desde luego, contra legem, ya que la equidad sigue a la ley (aequitas sequitur legem), y debe administrarse con mesura y equilibrio para que el convencimiento de que se ha aplicado con corrección la norma llegue a todos los litigantes; porque no hay mayor efectividad que mejorar la opinión del justiciable, sea beneficiado o perjudicado con la decisión final.

1 Carlos M. a Entrena KLett, La equidad y el arte de juzgar, Aranzadi, Pamplona, 1979, p. 84. 
Porque el Juez, como tutelador de la justicia efectiva, no es un simple instrumento técnico - lo que le deshumanizaría - ni es una calculadora a la que le dan los datos de las partes y aplica la norma de una manera mecanicista, sino que debe gozar de la prístina claridad de quien se siente dotado de un poder que procura la paz social, hace viable la convivencia privada, reprende a la Administración Pública o protege libertades. Su actuación, por tanto, no es de simple técnico, ni de funcionario sujeto a normas burocráticas. La labor tuteladora y efectiva se desmarca de los principios tecnócratas para adentrarse en la sublime tarea de preservar los valores superiores en una sociedad democrática. El poder no es otro que un poder derivado — como ya hemos dichopero cuya efectividad no se consigue en plenitud si no está signado por la norma ética y amparado por la equidad en la aplicación de la Ley, pero no extramuros de ella. Esa es la tutela intrínseca de la que está apellidado el poder judicial.

\section{2. ¿Es poder el poder judicial?}

Las voces más recientes llevan a manifestar de una forma nueva que los poderes del Estado, más que por una rivalidad, pasan por una influencia recíproca ${ }^{2}$, preguntándose cómo explicar que el control del Juez viene impuesto por el poder político. Nada más tenemos que observar el sistema de nombramiento de los miembros del Poder Judicial en España, para contestarnos que ello es cierto. Pero en mayor medida en la forma de acceso al Tribunal Supremo.

Si bien el Poder judicial responde a la teoría clásica de división de poderes, no podemos por menos de declarar que una política judicial no puede empañarse con una judicialización política. Y no salimos de nuestro asombro cuando oímos hablar de la «derecha judicial» o de la «izquierda judicial». Más sorpresa nos causa — como si estuviéramos en el siglo XVIII- que nos hablen de jueces progresistas o jueces conservadores. Casi siempre quienes hacen esta clasificación desean que en la sociedad existan clases y permanecen anclados en ideas $-\mathrm{y}$ sobre todo terminologías - que están caducas. (Así, quienes se titulan progresistas, emplean el término «patrón» para referirse al empleador o empresario; como se ve, lo que quieren conservar es una diferencia clasista entre señor y siervo. Al que llaman conservador, sin embargo,

2 Antoine Garapon, Juez y Democracia, F.V. (sin cita de edición, Depósito legal B., para la edición castellana. Odile Jacob, París 1996) 1997, p. 37. 
quiere una sociedad participativa en lo social en que desaparezca el término - y la actitud- «patronal», y en la figura de «empresario» se concentren los factores de la producción predominando lo humano.) Como se ve, los progresistas (?) están anclados en el pasado, mientras que los denostados conservan una actitud moderna y social. Quienes desde el Poder político se proclaman progresistas, desean un cambio en la composición del Poder Judicial acorde con su ideología monorrítmica y atemporal, para acceder a la imposición de su ideología; por el contrario, quienes desean un moderno concepto del Poder Judicial pretenden la constitución de éste por medio de un sistema democrático y social que lo haga independiente de las ataduras revolucionarias de la ideología más tiránica. Retomando la idea, la representación que concede el pueblo a los partidos políticos ha de manifestar la voluntad popular, que no es lo mismo que la emanación de un poder. Por este camino llegaremos a decir que una sentencia es de derechas o de izquierdas.

Tales apellidos causan rubor en una sociedad democrática — que debe alejarse de la trasnochada decimonónica dicotomía ideológicapues los jueces son, por ley, independientes y sometidos al imperio de la Ley.

Es cierto que la idea democrática ha de ser cambiante, como lo es la propia sociedad. Las últimas corrientes sobre la reinterpretación de la democracia dejan constancia de que «la democracia no descansa solamente en las leyes, sino sobre todo en una cultura política» (Alain Touraine). Pero añadimos que debe ser atendida como organización de la polis en que los poderes diferenciados estén al servicio de la sociedad. Un poder - el Judicial- que no se vea desdibujado por la consonancia con los otros poderes a los que le unen los siguientes caminos: A) Una sonda vigilante para que los «excesos» de los otros poderes sean controlados bajo la legalidad. Si quienes tienen que ser controlados nombran al controlador, la vigilia desaparece o se atenúa en los brazos del sueño prevaricador. Claro que se puede argumentar y preguntar ¿quién controla al controlador? La pregunta no está exenta de demagogia y sólo la hacen los que no desean ningún tipo de responsabilidad. B) Una norma para que las decisiones no sean arbitrarias, de manera que recibe el mandato legal del pueblo a través del parlamento. Pero una cosa es el mandato legal, y otra cosa el nombramiento. Cuando el Poder Legislativo dicta las leyes y se publican en el periódico oficial, han cumplido su misión y la tutela legislativa pasa a depender de otro Poder: el que tiene la misión de ejecutar. C) Por fin la relación con el Poder ejecutivo en una doble tarea: 1) por un lado, la vigilancia para que no se exceda aquel en su misión organizativa; 2) por otro, 
para que pueda coordinar de alguna forma las distintas facetas de la misión juzgadora (tales los edificios, el personal, la relación con los operadores jurídicos, etc.) $)^{3}$.

Cada una de ellas es una «intensa vigilia» a que se refería Maeztu. Porque la democracia no es sólo un sistema de elección más o menos puro, sino el acercamiento de las decisiones a las carencias del bienestar, es la tutela ejercida por el poder que desde la legitimidad del pueblo vigile a todo el entramado social. Un poder derivado siempre estaría maniatado al cauce de la ideología, apresado por quien le nombra.

Los apellidos a que nos referíamos antes claman al cielo en una Constitución que no los menciona y que la sociología o los poderes mediáticos tergiversan. El sometimiento a la Ley releva de cualquier apellido. Pero claro, si son nombrados por los partidos políticos, que ellos mismos se sitúan en el progreso - la mayoría de las veces falso y lo que llaman progreso es inmovilismo o vuelta atrás - o conservadurismo, no nos extraña que tales epítetos se endilguen a los jueces. El Poder Judicial es más serio que una película de buenos o malos. La Justicia —el Poder Judicial — no puede andar mercadeando decisiones bajo los aleatorios acuerdos de otros poderes. Nos bastaría que estuviera signado por la ética judicial, para juzgar, nombrar a los miembros de los Altos Tribunales, ejecutar lo juzgado con una profesionalidad fuera de toda intervención partitocrática.

Desde la Ley que regula el Poder Judicial podemos entresacar una serie de atribuciones que conforman el poder.

A) Poder consultivo. Emitir informe sobre los proyectos de ley que afecten a demarcaciones judiciales, Estatuto de Magistrados, Jueces, Secretarios Judiciales, y resto de personal al servicio de la Administración de Justicia. Leyes Penales, y las de «aspecto» (sic, art. 108 LOPJ) jurídico-constitucional. Tal consulta no es vinculante, porque, es obvio, no tiene la misión ni de proponer leyes (ejecutivo) ni de elaborarlas (legislativo).

Ser «oído», en el nombramiento del Fiscal General del Estado.

B) Poder decisorio. Con respecto a nombramientos de altos cargos de la Justicia. Así propone el nombramiento de dos miembros del Tribunal Constitucional (art. 159.1 CE y 107.2 de la LOPJ). Propuesta de nombramiento del Presidente del Tribunal Supremo (que lo es del CGPJ).

\footnotetext{
3 Nos acercamos así a la idea de LocKe, que combina el ejecutivo y el judicial. Comentado por GARCíA DE ENTERRÍA, Revolución francesa y Administración contemporánea, Taurus, Madrid 1972, pp. 26 y ss.
} 
Nombramiento de Magistrados del Tribunal Supremo, de Presidentes de Tribunales Superiores de Justicia y de Audiencias Provinciales. A quienes argumentan que tal «poder» es exclusivamente funcional se les escapa que los miembros que componen el Consejo son nombrados a su vez por el Poder Legislativo mayoritario en las Cámaras y cuyos candidatos van a presidir la cúpula decisoria de litigios entre Administraciones Públicas o dictar sentencias sobre cuestiones de gran repercusión social y política.

C) Poder burocrático, sobre inspección de juzgados y tribunales, presupuestos, publicaciones, etc.

D) Poder formativo. La selección, formación y perfeccionamiento de los Jueces es competencia del Poder Judicial, que en numerosos casos se transfiere a -o por lo menos se comparte con- las Comunidades Autónomas. La formación inicial y los reciclajes de los jueces tienen tanta importancia que de su eficacia depende la decisión final del juzgador. Una formación dirigida a una interpretación retorcida del Derecho ya dijimos más arriba que nos lleva a un uso alternativo del Derecho y que repugna a la balanza de la justicia y se contamina con otras apetencias o intenciones que las de llevar a la sociedad al establecimiento de un Estado Social y Democrático de Derecho.

E) Poder creador. Hay una tendencia doctrinal ${ }^{4}$ sobre teorizar ante la posible «capacidad de producción de normas». Se basa -Asís Roig - en que la actuación de los jueces tienen un valor jurídico real o «la interpretación de los enunciados». Bien es cierto que el artículo 1.6 del CC establece como complemento del ordenamiento jurídico la doctrina del Tribunal Supremo al interpretar y aplicar la Ley, la costumbre y los principios generales del Derecho. Es un poder con trascendencia normativa, alcanzando, en ocasiones, una fuerza unificadora para paliar la posible inseguridad jurídica. A veces, cuando el TS se «enfrenta» a una interpretación no conforme a la idea que de ella tenía el legislador, un cambio legal clarificador puede revocar aquella decisión. Nos encontramos ante un choque producido por una idea de la norma no acorde con el espíritu que imperaba la promulgación. Muchas veces, las «criptográficas» redacciones de las leyes tienen que llevarse a la aplicación por la interpretación de ellas que hace el Alto Tribunal. La falta de técnica jurídica de muchas leyes redactadas por tecnócratas debe ser ponderada por los Tribunales.

La relación entre los puntos E) y B) se hace evidente. Si se toma la decisión de nombrar a unos cualificados Magistrados — como una

${ }^{4}$ Rafael DE Asís RoIG, Jueces y normas. Pons, Madrid 1995, pp. 54 y ss. 
determinada tendencia- para el Tribunal Supremo al que le llegan asuntos o litigios de clave importancia en la vida política o económica, o sobre determinados procesos a altos cargos del Estado, no cabe duda de que la decisión del nombramiento anterior puede decantarse por una inclinación u otra. No estamos hablando de una interpretación subjetiva ni, por supuesto, prevaricadora, pero sí de una «atención» más proclive — por un humano razonamiento jurídico- a interpretar la ley por cauces permitidos por la norma, pero acordes con la actitud nombradora.

\section{El mandato tutelador del artículo 24 de la Constitución}

El artículo 24 de la Constitución española es, a nuestro juicio, un «apretado» concepto tutelador y con una clara vocación de garantía en las relaciones judiciales. Y fijándonos en la palabra, no he dicho jurídicas, que van por otro camino de los derechos fundamentales - que más tarde comentaremos-, sino que se centran en la relación del ciudadano con la justicia. El mismo Tribunal Constitucional ha dicho que tal precepto tiene «un contenido complejo» (s. 89/1985 de 19 de julio), y que su redacción «no ha conseguido expresar nítidamente el reconocimiento del Derecho a la jurisdicción $»^{5}$. El párrafo primero — que no es un dechado de perfección redaccional- dice así:

«Todas las personas tienen el derecho a obtener la tutela efectiva de los jueces y tribunales en el ejercicio de sus derechos e intereses legítimos, sin que, en ningún caso, pueda producirse indefensión».

Desmenuzando el precepto podemos advertir las siguientes connotaciones: 1) Cuando se refiere a todas las personas, se configura sin matices ni discriminación, sean personas físicas, jurídicas o entes colectivos. El concepto de persona, como es obvio, no es mismo que el del ciudadano a que se refiere el artículo 9.1 de la CE, pero al estar precedido del adjetivo «toda», no excluye a ningún ente que goce de la suficiente «personalidad». La tutela de los denominados «derechos» de los animales se encuentra también protegida por la acción que puedan interponer las personas o las asociaciones que los defiendan. 2) El derecho a que se refiere el artículo es una situación permanente de acción, pero

5 Angela Figueruelo Burrieza, El Derecho a la tutela judicial efectiva. Tecnos, Madrid 1990, p. 29. 
que no se ejerce hasta que se ve conculcado. Ello ha permitido distinguir entre la acción y la pretensión ${ }^{6}$, cuestión de la que ya nos ocupamos ${ }^{7}$ y que quedó claramente configurada en el trabajo de Guasp ${ }^{8}$. Sabemos que nuestros derechos se encuentran custodiados y vigilados por las normas constitucionales, nuestra acción permanece en reserva hasta que el derecho es conculcado y, en ese instante, se pone en marcha la misma a través de la pretensión, que lo que desea es «obtener» la respuesta de los tribunales. Acción y pretensión son dos momentos cronográficos distintos, pero que persiguen un mismo fin: la respuesta judicial. La acción es una consecuencia del ejercicio del derecho, la pretensión es una situación o momento con el que inicia un proceso, ambas son poseedoras potenciales de una satisfacción. 3) Todavía no hemos llegado al concepto de tutela efectiva, estamos en la posibilidad de obtención. Es un derecho de acceso (Figueruelo) para la petición de tutela cuando se conculca $-\mathrm{o}$ así se cree- un derecho individual o colectivo. No es la obtención de un guarda o vigilancia por medio de sistemas policiales de represión, acción protectora de los bienes y vidas, ni un derecho de ejercicio privado de los negocios jurídicos, sino que se enmarca en la obtención, previo ejercicio - acción- volitivo ante los juzgados - pretensión- de la satisfacción de un derecho. 4) El lugar no puede ser otro que los Juzgados y Tribunales, como componentes del Poder Judicial. La jurisdicción no protege en el sentido ejecutivo del poder, sino que se sitúa en un amparo una vez que el derecho ha sido conculcado. Podemos decir, con Figueruelo ${ }^{9}$, que el derecho a la jurisdicción es un «concepto instrumental». Aunque es un «instrumento» signado por tres pluses: a) que responde al ejercicio de un poder ciudadano como un derecho de los demás (art. 10.1. CE) y cuyo ejercicio compone, entre otros, la paz social; b) está alimentado por uno de los derechos fundamentales garantizados por la CE (art. 9.3) cual es la «seguridad jurídica»; y c) nadie más que los jueces puede ofrecer la tutela; es decir, que si la efectividad de la misma pudiera

\footnotetext{
${ }^{6}$ Figueruelo, op. cit., p. 31.

7 Isidoro AlvareZ SACRISTÁn, La pretensión en el proceso laboral. RL, Madrid, n.o 19 , 1989 , pp. 8 y ss.

8 Jaime Guasp Delgado, La pretensión procesal, Civitas, Madrid, 2. a ed. 1985, p. 75. «La pretensión procesal en cuanto declaración de voluntad es, pues, esencialmente una petición, y en este aspecto, conjugando los elementos subjetivos y objetivos ya conocidos, cabe sostener sin reparo que es una petición de un sujeto activo ante un Juez frente a un sujeto pasivo sobre un bien de la vida.» (Nosotros diríamos que es sobre un derecho.)
}

9 Angela Figueruelo, op. cit., p. 31. 
obtenerse por otras vías — arbitrajes, laudos, dictámenes, etc.— los jueces no tendrían la prerrogativa que les concede la $\mathrm{CE}$ de ser los únicos que pueden ofrecer una efectiva solución de sus demandas. 5) La tutela a que se refiere el precepto es para la protección de los intereses legítimos. Tal expresión no tiene una resolución unívoca, pues el interés legítimo no es otro que aquél que se corresponde con la legitimación para ser parte en un proceso, mientras que desde la sustantividad del Derecho tal interés puede situarse ex antes del proceso. Pero si relacionamos - y no puede ser de otra forma - el interés legítimo con el acceso a la jurisdicción, tal interés se procesaliza y se garantiza sólo a quienes ostenten la legitimación. Pero si tal acceso es ejercitado por quien «detenta» el interés, sólo a través del proceso se podrá saber si está legitimado para comparecer ante el órgano tutelador, o no. Por lo tanto, el interés legítimo desde el acceso constitucional a la jurisdicción es una tutela de la Carta Magna, pero no se virtualiza nada más que a través del proceso ${ }^{10}$. El Tribunal Constitucional así lo tiene dicho:

«el derecho a la tutela judicial efectiva puede verse satisfecho con una resolución de contenido meramente procesal, siempre que se base en una argumentación fundada y razonablemente derivada de las normas procesales que resulten de aplicación» (S. 11 de julio 1994, BOE 4-8-94).

Con este planteamiento la sentencia que se cita quiere que la legitimación tenga una conexión con la acción-pretensión, o, lo que es lo mismo, con el proceso. El acceso es para «todos», pero una vez en él se decidirá su legitimación. De manera que los legitimados constitucionalmente pueden no estarlo procesalmente, y por eso no quiebra la tutela jurisdiccional, ya que el poder de ejercitar la acción, responde el Poder con acceder a ella, pero pasándola por el tamiz de las Leyes procesales. La duda surge enseguida: si todos tienen derecho a obtener la tutela, ¿por qué a uno sí y a otros no? La respuesta es bien obvia, el

10 El problema de la legitimación ha sido complicado y mucho más nos lo complica la Constitución, pues bastaría con dejar sentado que se accede por interés, ya que hasta que no se accede al proceso no se sabe si es legítimo o no. Desde CALAmandrei, Derecho Procesal Civil, tomo I, p. 261, hasta Montero Aroca, La legitimación en el Proceso Civil, Civitas, 1994, pasando por el trabajo de Antonio Esteban Drake, El Derecho Público subjetivo... y el problema de la legitimación procesal. Civitas, Madrid, 1990, el problema no ha sido resuelto con claridad, dada la complejidad de las relaciones privadas y el acceso subjetivo a la jurisdicción. 
concepto de efectiva no quiere decir estimada, ni quiere decir que los intereses particulares estén signados por el Derecho. Un interés particular puede ser tan legítimo como el del contrario, pero sólo uno de los dos es poseedor de la justicia. Ahora bien, aun a pesar de que se invoque un interés legítimo, las normas procesales pueden impedir su acceso. Bien por no estar en pleno ejercicio de sus derechos civiles (art. 2 LEC) o bien por falta de representación, o por no reunir alguno de los requisitos procesales de la legitimación.

Es evidente que el acceso a la jurisdicción —ya que no son órganos consultivos - sólo resulta eficaz para el proceso cuando los derechos han sido violados. Esta es la expresión a que hace referencia el Pacto Internacional de Derechos Civiles y Políticos (art. 2.3.): «toda persona cuyos derechos y libertades... hayan sido violados...». La protección de los derechos y libertades no corresponde al Poder Judicial sino al Ejecutivo, sólo cuando se violan aparece la tutela del Juez.

\section{El papel mediador del juez}

Al principio del capítulo, advertíamos de los elementos que podían componer la acción-obtención de la justicia. Entre ellos el elemento jurisdiccional. Dentro de este elemento, se sitúa el juez como hacedor independiente $^{11}$ y con un papel de mediador $^{12}$, pero «sinónimo de libertad e igualdad» ${ }^{13}$ y garante de un Estado Democrático y Social de Derecho. Lo que está haciendo el Juez es «propugnar» ni más ni menos que un valor superior cual es la justicia, sin la que no sería posible ni la libertad, ni el pluralismo político que proclama la Constitución. Tiene razón Peces Barba que la justicia «o es sinónimo de libertad e igualdad, o está vacía de contenido o produce más problemas que los que resuelve su utilización» ${ }^{14}$.

Como valor superior trasciende el Estado de Derecho, pues para su eficacia pasa por el imperio de la Ley, la garantía jurídica, la división de poderes y la sumisión del Poder ejecutivo al principio de legalidad ${ }^{15}$.

11 Sobre la independencia judicial ya tratamos en el capítulo segundo.

12 Teoría de Lucas Verdú criticada por Gregorio PeCES BARBA, Los valores superiores, Tecnos, Madrid 1986, p. 147. El papel de la justicia se acerca más al elemento instrumental que al jurisdiccional.

${ }_{13}$ Op. cit., p. 146.

14 Idem.

15 Como concepto eje del «Estado de Derecho» a que se refiere Oscar Alzaga, La Constitución española de 1978, Foro, Madrid, 1978, p. 77. 
Es evidente que ante esta presencia de la justicia, el papel del Juez es, si no de mediador, por lo menos de conciliador, para que se cumpla la glosa que de las Partidas hacía Gregorio López: «todos los juzgadores deben ayudar a la libertad, porque es amiga de la natura» ${ }^{16}$.

Este papel pasa por los siguientes parámetros:

A) Entre la libertad y justicia. Parecería que cuando se coloca redaccionalmente en un mismo plano a los valores libertad - juntamente con igualdad y pluralismo político- - y justicia son de idéntica naturaleza. Evidentemente no es así, pues, en todo caso — como apunta Alzaga—, no son superiores del sino, en todo caso, superiores al ordenamiento jurídico. Decir que la justicia es un valor superior de su ordenamiento jurídico es un pleonasmo. ¿La justicia es superior a lo jurídico, o lo jurídico debe ser justo? Que la propia Constitución nos sitúe en tantas dudas filosóficas no deja de ser una paradoja. Por lo menos, la justicia protege la libertad y, por ello, los jueces examinan los valores superiores a los que amparan, y condenan los disvalores a los que proscriben. Tal amparo camina por el aforismo de Bacon «el Magistrado es la ley parlante; la Ley es el Magistrado silencioso». Si bien la CE ordena a todos promover los valores, el Tribunal Constitucional ha dejado dicho que «la obligación de los poderes públicos que es promover la real y efectivamente las condiciones para la libertad y la igualdad de individuos y grupos...» (S. TC 19-12-1994). Cuando ese mandato no se cumple aparece la jurisdicción a través del juez. La tutela judicial que proclama la Constitución, lo es para los derechos, y para las libertades. Cuando al amparo de tales libertades, el individuo o la persona puede elegir entre varias opciones vitales - S. TC 18-6-1989- que se le presentan de acuerdo con sus preferencias e intereses, y alguien se opone a ello, el acceso a la jurisdicción -elemento instrumental - concede el Poder una actuación personal de un juez. Lo de menos es el nombre que le demos, lo importante es que acude a mediar (estar en medio, poner paz, arreglar). Bien es cierto que no es un árbitro ni un componedor de controversias, sino supremo - y únicotutelador de la libertad.

B) Entre Poder y poder. Una tarea difícil, pues nos estamos refiriendo a los «poderes públicos». A las controversias entre varias Administraciones; entre los «poderes» fácticos o los «poderes amediáticos». Ardua tarea la de los juzgadores. Cuando se trata de actos de la Administración sujetos a Derecho administrativo y las disposiciones reglamentarias es al orden jurisdiccional — a sus jueces - a quien corresponde la atención

16 Gregorio LóPeZ, Glosa a las Partidas, L.I., Tít. 34, Part. VII. 
(art. 9.4 LOPJ). Y también cuando se trata de actos de las Comunidades Autónomas, el control corresponde a la misma jurisdicción contenciosaadministrativa.

Una influencia de otros poderes ante el juez puede llevarle a decidir sobre una realidad que escapa de la legalidad. Se dice que «el juez garantiza los intereses de la justicia, ya no como antes, sino manteniendo con la realidad que se le encomienda una relación de nuevo tipo, a la vez más concreta y más atenta a ciertos principios (y) le corresponde al juez actualizar y contextualizar sin descanso su espíritu. No se trata por tanto de una capitulación de la justicia sino, por el contrario, de su preocupación de asumir la pérdida de criterios sustanciales de justicia querida por la democracia ${ }^{17}$. Bajo estas palabras que entierran un criterio único de verdad, al decir de Garapon, el juez accede por la vía interpretativa en el fiel de su labor de centro o mediación en la interpretación de la realidad social (cuestión que, por otra parte, quiere que así sea el art. 3 del CC).

Las normas que debe aplicar el juzgador son cambiantes y la cadena de situaciones sociológicas que influyen en las leyes y, por supuesto, en los jueces, que si no están avezados en la impronta del cambio social, pueden producir con sus decisiones el pernicioso divorcio entre la realidad social y la anacrónica norma jurídica, determinando una ucronía que, por un lado, produce en el justiciable una sensación de desamparo $\mathrm{y}$, por otro, un desajuste sociopolítico de consecuencias imprevisibles ${ }^{18}$. Reconociendo que, de momento, no existe un mecanismo, ni político ni social, que pueda desarrollar la norma en el impreciso momento en que se produce el cambio social, hemos de acudir al momento de su aplicación - allí sí hay momento preciso histórico-y adaptar el cambio social al Derecho. Es evidente que el hecho social o la conducta individual se aprecia de distinta manera según la época, el lugar o las personas. El Derecho es contestado por la sociedad, al contrario que en épocas pasadas para juridificarlo. Pero la llamada espontaneidad del hecho social dificulta la reacción súbita del Derecho; que, aunque vivo y cambiante, no puede aplicarse desde una directriz sociológica transida de veleidades extraparlamentarias, nacidas de acciones fugaces o improntas de minorías no consolidadas en el poder legislativo.

Si el artículo 3 del CC nos marca que el juez debe interpretar la norma conforme a la realidad social del tiempo en que han de ser

\footnotetext{
17 Antoine GARAPON, op. cit., p. 248.

18 Isidoro Alvarez SACRISTÁN, «La interpretación de la norma conforme a la realidad social». Boletín del Colegio de Abogados de Madrid, n. ${ }^{\circ}$ 5/1987, pp. 71 y ss.
} 
aplicadas, lo hace bajo la sabia decisión de dar luz a la norma antigua u oscura. Una luz que no puede ampliarse sobre un hecho social aislado en el tiempo y en el espacio, sino que debe estar armonizada con el contexto del resto de la normativa. Esto es así porque las circunstancias o situaciones sociales en las que se produce el nacimiento de una ley — proposición, discusión o desarrollo parlamentario- están presididas por movimientos ideológicos, transacciones políticas, influencias o presiones, quizás huelgas; y pasadas aquellas situaciones queda la letra. La tarea no es fácil, como lo dijo el TS en sentencia de 22 de abril de 1986:

«El elemento sociológico, como criterio interpretativo previsto en el artículo 3.1 del CC, se halla integrado por aquella serie de factores ideológicos, morales y económicos que revelan y plasman las necesidades y el espíritu de la comunidad en cada momento histórico; datos que deben valorarse con cautela, ya que estos factores, aparte de que no pueden nunca autorizar al intérprete para modificar o inaplicar la norma, y sí sólo para suavizarla hasta donde permita el contenido del texto que entra en juego, requieren en su utilización mucho tino y prudencia, porque envuelven grave riesgo y arbitrariedad al entregar al criterio subjetivo del juez apreciaciones tan delicadas como la conciencia moral de un pueblo»

Como se puede apreciar — el subrayado es nuestro- nos lleva a la dicotomía entre subjetivismo-objetivismo. No puede llegarse a una apreciación «subjetiva y sentimental del intérprete», como argumenta Batlle $^{19}$, sino que tal decisión no es permisiva sino interpretativa en conjunto con otras realidades. No se trata, por tanto, de una mediación permisiva, como algunos piensan, sino de que el espíritu de la norma no se convierta en entelequia pasado el tiempo de su promulgación. Su empleo - como se dice en la exposición de motivos de la reforma del CC de 1974 y que la doctrina ha seguido- es «ciertamente muy delicado» y, como nosotros hemos subrayado, debe emplearse con «tino y prudencia», ya que su utilización no está exenta de subjetivismos jurídicos, pues la llamada directriz sociológica no puede ser un cajón de sastre del que se sacan adminículos que, como dice el refrán, igual valen para un roto que para un descosido. La norma, como recuerda la doctrina jurisprudencial constantemente, no puede interpretarse de una forma aislada sino que debe serlo a través de lo contextual, lo histórico

19 Manuel Batlle Vázquez, Comentarios a las Leyes Civiles, Madrid 1979, Tomo I, p. 84. 
y lo social. La mens legislatoris de los días de su promulgación debe inspirar la objetivación actual, es un salto de mentalidad. El juez que no esté preparado con tal avío no podrá adoptar en su decisión las nuevas concepciones jurídicas. Debe primar, por tanto, la interpretación coetánea al situarse entre los poderes. Tiempo y realidad social componen el binomio por el que quien juzga ha de hacer discurrir sus decisiones. Ya no es el funcionario que aplica el Reglamento, que se sabe de memoria los códigos o que estudia, en aislamiento, la construcción correcta de una sentencia técnicamente perfecta, sino que su realidad social hace que sea partícipe de su entorno, de $s u$ cambio, de $s u$ devenir. Se convierte así en un segundo intérprete de lo que demanda el pueblo (el primero es el Parlamento). Ahora bien, la realidad social no es sólo su contenido sociológico (encuestas de opinión o poder mediático), sino que está signada de contenido jurídico. Y éste no puede ser otro que la asunción por el intérprete de los valores constitucionales. Ya lo dijo el Tribunal Constitucional: entre varios sentidos posibles de una norma o entre varias interpretaciones hay que aplicar la más ajustada a la Constitución. Lo que se desea es que los juzgadores que se sitúan entre los poderes sean hombres vivenciales, asequibles a la modernidad, diseñadores de la realidad social, pero siempre teniendo presente la juridicidad permanente, pues la justicia no puede seguir a fugaces veletas sino a una realidad consolidada como valor superior.

C) Entre poder público y poder privado. Cuando el artículo 106 de la CE ordena a los Tribunales que controlen la potestad reglamentaria y la legalidad en la actuación administrativa, y cuando el artículo $53 \mathrm{CE}$ liga a «todos los poderes públicos» a guardar y respetar los derechos y libertades, está ordenando a los jueces a soportar la carga de ser vigilantes de las decisiones de la Administración Pública con respecto a las administradas y la salvaguarda de aquella de las decisiones injustas de los ciudadanos o de otros entes sociales. Para algunas interpretacione ${ }^{20}$ el Derecho privado es servidor de la clase media como concepción neoliberal y que subordina, por tanto, el derecho privado a la realidad económica. Nada más lejos de la realidad; por la mediación del juez, al contrario, se ampara la decisión unilateral del Poder ejecutivo alejándolo de la prerrogativa o factum principis, pues el ciudadano no es servidor del Derecho Público, es decir, de la unicidad del Estado, sino que es agente en convivencia constante con las normas

20 Ulrich MüCKEnBERgeR y Dieter HART, «La formación de los juristas...», con BARCELLONA, en La formación del jurista, Civitas, Madrid, 1991, p. 71. 
dentro de un Estado democrático y social de Derecho. Quiere decirse que no está a merced del gobernante más caprichoso ni éste de la omnímoda presión de grupos o personas. Al Juez le corresponde ser el garante no de clase, como quiere Mückenberger, sino de los derechos de las personas que «le son inherentes».

Queda claro que en todas las sociedades regidas por un Estado Democrático, las Administraciones Públicas están sometidas a la ley. Es, al decir de Larenz ${ }^{21}$, una «estrecha vinculación», asegurando la decisión final del Parlamento y «controlados por los Tribunales Administrativos si sus decisiones son jurídicamente vinculantes para los ciudadanos». Es cierto que — como sigue diciendo Larenz- «el funcionario también interpreta la ley cuando la aplica; pero si el asunto se convierte en litigioso, el Tribunal decide si su interpretación era o no la correcta. En esta medida se puede hablar de un monopolio judicial de la interpretación». Es una decisión judicial que no le vincula a la Administración, por más que ésta sirva los intereses generales ya que el valor superior está, por evidente interpretación gramatical, por encima de cualquier decisión afectativa. El control del juez consiste, como argumenta Parejo ${ }^{22}$, en comprobar si existe contradicción o no entre el ordenamiento y la decisión administrativa. Tal acto administrativo puede afectar a otra administración o los ciudadanos; y en sentido contrario, el Juez controla las actuaciones ciudadanas que pueden perjudicar al patrimonio público.

Otra cuestión de la que ya hemos apuntado alguna tesis es la mediación controladora entre la actuación del poder político cuando éste se excede de sus funciones democráticas y constitucionales. No es de extrañar, por tanto, que se trate de mediatizar a través de los partidos políticos la decisión judicial.

D) Entre poder judicial y poder orgánico. Es lo que puede llevar a «controlar al controlador». Dos cuestiones aparecen - y de grave trascendencia- en las tomas de decisión del juzgador que debe juzgar a otros iguales: 1) la procedencia nominativa de quienes deben emitir juicio y, 2) la desaparición de la prerrogativa que tenían los jueces de someterse al «antejuicio». La primera cuestión objeto de controversias mediáticas debe estar alejada de toda duda de que los jueces que decidan la responsabilidad — sobre todo penal— de otros compañeros no se vean coartados por influencias exógenas al poder que el pueblo les ha dado. Si la influencia es política al socaire de que

21 Karl LaRenZ, Derecho justo, Civitas, Madrid, 1991, pp. 166, 168.

22 Luciano Parejo Alfonso, Administrar y juzgar..., Tecnos, Madrid, 1993, p. 58. 
los partidos son los auténticos elegidos por los ciudadanos, la cuestión se complica más; y si la influencia es corporativa, la crítica mediática arreciará aún más. ¿Dónde la independencia y la libertad de juzgar? La mediatización aleja al juzgador del equilibrio necesario para la decisión final; como ya dijo Paulo, no es válido lo actuado por un juez fuera de las funciones de su cargo. Y quien lleva el peso de la toga no puede obnubilarse por la niebla de la participación política o de los medios de masas. Pero, por el contrario, no debe ser cohorte de cualquier otro poder que pretende absorberle de sus funciones.

La otra cuestión que tenía una larga tradición, como es el antejuicio de Jueces y Magistrados cuando se les exigía responsabilidad penal en el ejercicio de las funciones de su cargo, fue derogada por la Ley 5/1995 — del Jurado, de infausta promulgación-, cuyo contenido estaba en la LOPJ, en su artículo 410, y que permitía la posibilidad del «antejuicio», a través de un Tribunal que decidiría si se admitía la querella o no. Era una prerrogativa en similares condiciones a las de los Diputados o Senadores o las de los altos cargos de la Administración, pero, por lo visto, el poder de los jueces se sitúa en un lugar más bajo que el resto de los poderes. Quien tiene el privilegio de legislar se da sus propias normas y, además, las de los que tienen que vigilarlo. La situación de jueces que son víctimas de querellas infundadas y que con un mínimo de «indicio» de delito son juzgados sin previa comprobación del querellante, puede llevar al desprestigio constante del juzgador y de la institución, o del poder que sirve a la sociedad. La medida de suprimir tal instituto, con gran raigambre en el tiempo y con ningún peligro de que se eximiera a los jueces de su responsabilidad, no ha sido acertada. Parece como si se desconfiara de la decisión judicial o que se apreciara una inclinación corporativista.

\section{El elemento personal de la tutela judicial}

Tiene su base en la «dimensión subjetiva» ${ }^{23}$ de los Derechos Fundamentales. Si al elemento jurisdiccional a que antes hemos aludido le añadimos el elemento personal, ya tenemos formado el binomio que va a discurrir entre los instrumentos que se ponen al servicio de los justiciables. Ante esta «dimensión» aparecen dos variantes:

A) En primer lugar los sujetos portadores de derechos fundamentales — de valores- que se entrelazan en la esfera privada de los individuos y

23 Antonio E. Pérez de Luño, Los Derechos Fundamentales, Tecnos, Madrid, 1986, 2. ${ }^{\text {a }}$ Ed., p. 22. 
los entes, que son perseguidos por las Administraciones Públicas que deben encaminarse a «promover la libertad y la igualdad del individuo y de los grupos». A quien protege, por tanto, es a los sujetos que son portadores de igualdad. Es decir, que lo que la tutela garantiza son «derechos subjetivos», «en cuanto garantizan el status jurídico o la libertad en un ámbito de la existencia» ${ }^{24}$. Lo que manda la Constitución (art. 9) va dirigido tanto a los sujetos privados como a los sujetos públicos. Pero con dos connotaciones respecto de cada uno de ellos. Para los poderes públicos la actuación ha de ser dinámica, pues les ordena promover las condiciones para que impere la libertad y la igualdad, y les ordena remover obstáculos que impidan u obstaculicen su plenitud, esto es, la consecución completa sin cortapisas o disminuciones, es decir, con carácter de generalidad. Tal mandato origina una búsqueda de medios para lograr que la realidad se acerque a los principios rectores» (S TC 24-11-1987), medios que se encuentren en el amplio marco de un Estado Democrático y Social de Derecho, que bien pueden ser las leyes a través del Poder Legislativo o la actuación judicial a través de los sistemas de acceso a la justicia. Son en fin actitudes positivas y diligentes para caminar por las vías ex Constitutione, camino al que se incorporan los sujetos tutelados. Para los individıos y grupo la actitud es, en principio, estática, pues nada puede hacer en la esfera individual y privada para conseguir el fin constitucional, su aceptación del sistema político vigente y la elección de quienes le han de dar las normas hace que «confíe en que el poder legislativo le va a conceder el privilegio de que su quehacer discurra por los campos de la libertad y la igualdad. Sólo la actitud estática se pone en marcha y dinamiza la voluntad, cuando accede a la jurisdicción. Si el ciudadano no observa que es tutelado, comienza a surgir un "sentimiento reivindicativo" 25 que si no se atiende pasa a otro estadio, como es la insolidaridad, la indolencia, la desconfianza en la justicia, en fin».

B) Si la Constitución garantiza todos estos derechos - pero sobre todo la libertad y la igualdad - en un conglomerado que bastaría con definir como seguridad jurídica, dando a este término la expresión de tutela de cualquier origen constitucional, corresponde a los elementos subjetivos promover la actividad —o soportar la acción — siendo, en definitiva, sujetos activos y pasivos del proceso tutelador, en lo que Aragoneses ${ }^{26}$ ha

\footnotetext{
24 PÉreZ de LuÑo, op. cit., p. 25.

25 Gregorio Robles Los Derechos Fundamentales y la ética en la sociedad actual, Civitas, Madrid, 1992, p. 35.

26 Pedro Aragoneses, Proceso y Derecho Procesal, EDERSA, Madrid, 1997, p. 151.
} 
llamado «un proceso supra-autónomo», compaginadores del principio de igualdad de partes ante la tutela. Cuando la tutela acude a unos sujetos sí y a otros no, se rompe el valor superior de igualdad y es un obstáculo que hay que remover o en ocasiones, sancionar.

C) Desde que se constitucionalizaron los derechos naturales, el avance en la consecución de derechos ha sido constante y, a veces, en detrimento de la solidaridad o deberes que, antaño, parecieran inconmovibles (la pena de muerte, el servicio militar obligatorio, etc.) y hogaño se tornan un valor imposible de desbancar en una sociedad democrática. Como ha quedado dicho (Gregorio Robles), «es un hecho social palpable que en la sociedad de nuestros días el sentimiento del deber empalidece, con frecuencia se muestra extinguido, mientras que su contrario, el sentimiento reivindicativo, alcanza mayores cotas de intensidad». No es extraño, por tanto, que diariamente se vean colapsados los juzgados en demanda de justicia. Los ciudadanos no sólo se mueven por circunstancias provenientes de conculcación de un derecho individual o colectivo sino que se mueven por la «circunstancia» sociológica de la comparación. El elemento personal pasa desde la sociologización a la juridicidad sin que apenas exista un camino trazado legalmente, sino que se contrae por alguna impronta que no tiene su nacimiento en ningún momento impreciso. Cada vez son más las demandas basadas en acciones declarativas de derechos, cuya admisión ante los Tribunales era anormal y, en la actualidad, se decantan tanto de la acción de condena como la declarativa. (Buen ejemplo de ello son las acciones en el orden jurisdiccional social, sobre todo en los conflictos colectivos. $)^{27}$

D) Por lo que respecta a los titulares del Derecho - a los que nos hemos referido más arriba- el TC ha mantenido una clara tendencia «amparadora» al permitir el establecimiento de una doble garantía para «todas las personas», como una situación positiva al permitir a quienes se encuentren en pleno ejercicio de sus derechos e intereses

27 Especial mención merece la Sentencia del TS, Sala 1. a de 8 de noviembre de 1994, La Ley, Ref, 1995, 211. «Aunque la LEC no reconozca de modo expreso la posibilidad de acciones meramente declarativas, tanto en la doctrina como en la jurisprudencia admite el ejercicio de esas accioncs y de hecho no son infrecuentes en la práctica, en especial, en el campo de los derechos reales. Este tipo de pretensiones no intentan la condena del adversario, sino que se declare por medio de sentencia la existencia de una determinada relación de derecho puesta en duda o discutida; no buscan, por ello, la obtención actual del cumplimiento coercitivo del derecho sino la prueba en claro del mismo. No obstante su ámbito es restringido, pues de la acción declarativa sólo puede valerse quien tiene especial necesidad para ello: debe existir la duda o controversia y una necesidad actual de tutela...» 
legítimos, sino que prohíbe - conducta negativa - al legislador que «con normas excluyentes de la vía jurisdiccional, le impida el acceso al proceso» (TC S. 99/1989, de 5 de junio).

\section{La tutela ordinaria y el amparo}

Como elemento instrumental para el acceso a la tutela es, obviamente, la jurisdicción o el proceso debido y al que se accede a través de los distintos órdenes jurisdiccionales denominados - no muy correctamente, ya que no hay extraordinarios, que desaparecieron por la LOPJ - ordinarios a través de las distintas modalidades procesales, acciones, pretensiones, etc. y que «se extiende a todas las personas, a todas las materias y a todo el territorio en la forma establecida en la Constitución y las Leyes» (art. 4 LOPJ), mandando la misma Ley a todos los Jueces y Tribunales interpretar y aplicar las leyes de acuerdo con los principios constitucionales. Tal mandato relevaría de cualquier acción ante el amparo constitucional si los instrumentos que las leyes ponen al alcance del justiciable devinieran en cumplidores estrictos de la Constitución. Cualquier norma procesal o sustantiva que contraríe los principios inspiradores de la Carta Magna, debe ser preterida, sin aplicación práctica alguna en el proceso; y si se tratara de actos entre particulares o entre la Administración y los ciudadanos puede acudir a los Tribunales «ordinarios». Pues cualquier disposición (del rango que sea) queda derogada si se opone a lo establecido en la Constitución (D. Derogatoria tercera CE). Para decidir sobre la inaplicabilidad de la norma inconstitucional se debe aplicar el criterio «jerárquico», pues la Constitución es una ley superior, y el criterio «temporal», ya que es posterior, pero además, y lo más importante, es que aquella deviene en invalidez y "pérdida de vigencia» (S TC 4/1981 de 2 de febrero). Lo matiza más el TC en sentencia del 20 de diciembre de1982, 77/82:

«Si la ley reguladora del derecho fundamental es anterior a la Constitución e infringe ésta, no cabe duda que debe considerarse inaplicable en lo que vulnere dicha norma constitucional por haber quedado derogada. Lo mismo debe concluirse, y con mayor razón, cuando la norma que vulnera lo dispuesto en la Constitución Española es de naturaleza reglamentaria, y todo ello sin necesidad de que el legislador, la Administración o los Tribunales, según los casos, hagan una declaración en tal sentido».

La CE en su artículo 53.2 permite a los Tribunales ordinarios la protección de libertades y derechos en ella reconocidos, y como el mis- 
mo TC ha dicho no tiene la «última palabra» sino la «primera palabra» (S TC 59/1990 de 29 marzo). El citado artículo 53.2 se remitía a un procedimiento de preferencia y sumariedad. No se ha promulgado tal procedimiento especial, pero sí existen algunas modalidades que pueden amparar tal mandato y en las cuales pueden los justiciables acudir en demanda de amparo cuando se trate - especialmente- de decidir sobre libertades y derechos fundamentales:

— Ley 62/1978 de 26 de diciembre de Protección Jurisdiccional de los Derechos Fundamentales de la Persona ${ }^{28}$, que permite el ejercicio de los derechos fundamentales y «gozará de garantías jurisdiccionales». Se refiere a los derechos de libertad de expresión, reunión, secreto de correspondencia, etc. La disposición Final de la referida Ley - preconstitucional — ya atisba la promulgación de la Constitución de 1978, al decir que «se podrán incorporar al ámbito de Protección de esta Ley los nuevos derechos constitucionalmente declarados». No obstante, en la DF se está a la espera de «regular definitivamente el procedimiento jurisdiccional».

—Ley Orgánica 1/1982 de 5 de mayo de Protección Civil del Honor, la intimidad personal y la propia imagen, que se promulga - según su exposición de motivos- «de acuerdo con lo prevenido con el artículo 53.2 de la Constitución». Se protegen «civilmente» y cuando sea constitutiva de delito se estará a lo dispuesto en el Código Penal (Títulos X y XI del CP) ${ }^{29}$.

— Ley Orgánica 2/1984 de rectificación. Si no se rectifica por el medio previsto podrá acudir al Juez de $1 .^{\text {a }}$ Instancia en procedimiento verbal.

— LO 9/83 de Derecho de reunión. Ante su prohibición puede interponerse recurso contencioso-administrativo, por los trámites del arículo 7.6 de la Ley 62/1978.

— Real Decreto Legislativo 2/1995 de 7 de abril de Procedimiento Laboral -que como en tantas otras cosas es una Ley «adelantada»- se contiene en el Capítulo XI del Título II, del Libro II, y en su artículo 181, la modalidad procesal de las demandas de

28 Se ha dicho que «como es sabido, como la principal de entre las normas de desarrollo del artículo 53.2 CE... aunque presente la paradoja de que su entrada en vigor es anterior a la Constitución. Alfonso MARTínez EsCRIBANO, El marco Constitucional al amparo judicial ordinario, CGPJ, 1994, Vol. XXVII, p. 65.

${ }^{29}$ Hay que citar la LO 6/1984, de 24 de mayo, del procedimiento del Habeas Corpus: solicitado, en su caso, ante el Juez de Instrucción. 
tutela de los demás derechos fundamentales y libertades públicas incluida la prohibición de tratamiento discriminatorio que se suscite en el ámbito de las relaciones jurídicas atribuidas al conocimiento del orden jurisdiccional. Si bien es cierto - como se ha argumentado 30 - que se colma con esta modalidad procesal el acceso a los Tribunales ordinarios para la protección de los derechos fundamentales, no lo es menos que la invocación actual de los mismos también puede extenderse a los razonamientos jurídicos que amparen la causa petendi de cualquier acción siempre que se pruebe la relación entre la questio factio y la questio iuris.

Hay que hacer especial mención, a este respecto, a la redacción que da la Ley 5/1997 de 4 de diciembre al artículo 240 de la LOPJ. Es, en verdad, una solución histórico-procesal y atemporal del problema que suscitó el artículo 53 de la CE. No parece del todo creíble que tal norma -incorporada a una Ley que no es estrictamente procesal- dé respuesta al desarrollo de aquel precepto, a pesar de que en la exposición de motivos de la reciente Ley así se diga. Si, como ha quedado patente, la acción ante los Tribunales Ordinarios para recabar tutela por violación de derechos y libertades fundamentales se encuentra en procedimientos fragmentarios y diversos ${ }^{31}$, la redacción dada de la LOPJ, ni «desarrolla» el artículo 53.2 de la CE, ni viene a aclarar nada que no se hubiera podido hacer a través de los recursos correspondientes. Lo que parece desprenderse de tal redacción es liberar al Tribunal Constitucional de la carga de asuntos que llegan a él a través del amparo, por medio de que los Juzgados y Tribunales puedan entender sobre la posible nulidad radical de actuaciones procesales, tanto antes de recaer sentencia definitiva, como una vez que la sentencia sea firme. Esta última posibilidad es la novedad que contiene — si bien con carácter extraordinario- la reforma del arículo 240 de la LOPJ.

Si bien no es el lugar ni el momento de comentar tal precepto, no nos parece oportuno ni por la forma ni por el fondo que exista relación alguna entre el artículo 53.2 de la CE y el artículo 240.3 de la LOPJ. En primer lugar porque nada se dice de que la nulidad de actuaciones a instancia de parte se efectúe a través de un procedimiento «preferente y sumario» (la nulidad se puede pedir hasta los cinco años), tampoco se

30 Pedro Luis Serrera ConTreras, «La protección ordinaria de los derechos fundamentales», Actualidad Aranzadi, n. ${ }^{\circ}$ 173, noviembre 1994.

31 Serrera Contreras, op. cit., ifra, p. 5. 
aclara si los «defectos de forma, que hubieran causado indefensión o incongruencia del fallo» ${ }^{32}$ deben estar ínsitos en los supuestos de libertades y derechos fundamentales (aunque si la indefensión). Lo que la Ley quiere que sea excepcional se va a convertir en cotidiano, con lo cual se introduce otro proceso y, a la larga, si no se reforma la LOTC va a terminar en el propio TC.

Si la reforma no es desarrollo del arículo 53.2 de la CE, los procedimientos para tal amparo por los Tribunales ordinarios siguen su cauce por el medio instrumental de las leyes citadas cuando la violación de los derechos lo es por los particulares, ya que el artículo 240 de la LOPJ se está refiriendo a violación de aquellos por las Resoluciones judiciales. Es lo que se ha dado en llamar la «eficacia inmediata» ${ }^{33}$ de los derechos fundamentales y que deja a discrecionalidad de los jueces la composición heterónoma de la norma constitucional sin ser el Tribunal que se crea ad hoc para ello. Antes ello se opone que no se trata de dar al juzgador un poder discrecional, ya que «el Juez nunca puede sustituir al legislador en aquellas cuestiones en las que es lícito adoptar distintas posiciones, todas ellas igualmente constitucionales» ${ }^{34}$. Por otro lado, añadimos nosotros, la labor constitucional del juzgador le nace - y le obliga - porque «vincula a todos los Jueces y Tribunales» (art. 5.1 LOPJ), en cualquier procedimiento, sea o no de carácter extraordinario para la protección de libertades y derechos fundamentales; y una vez que estos no hubieran sido respetados, «en su caso», a través del «recurso de amparo», ante el TC.

Es bastante común que se oiga decir que ante una sentencia «cabe recurso ante el Tribunal Constitucional». Ello no extraña, ya que la misma Constitución llama recursos a la impugnación de inconstitucionalidad o al amparo por violación de derechos y libertades. El TC no es la cúspide de la pirámide jurisdiccional, ya que no es estrictamente «poder judicial», sino que se mueve por otros parámetros institucionales. Quien, en principio, debe velar por tales derechos y libertades son los Tribunales «ordinarios», ya que la actuación del TC es «sin perjuicio de su tutela general encomendada a los Tribunales

32 Creemos que la redacción correcta podría ser: «defectos de forma esenciales del procedimiento o incongruencia en el fallo, que hubieran causado indefensión o vulneración de derechos y libertades fundamentales». De las primeras resoluciones aplicando el nuevo artículo 240.3 de la LOPJ, se contiene en el Auto de la Sala de lo Social del TSJ del País Vasco de 30 de marzo de 1998, REC/1731/97.

33 Tomás QuAdRA-SALCEDO, El recurso de amparo y los derechos fundamentales en las relaciones entre particulares. Civitas, Madrid, 1981, p. 65.

34 Tomás QuAdRA-SALCEDO, op. cit., p. 66. 
de Justicia». La misión del amparo no es, por tanto, un instrumento alternativo de acción jurisdiccional, sino que es subsidiario o vigilante. Primero corresponde a los Tribunales la protección, pues el artículo 44 de la LOTC es claro al respecto: que se hayan agotado todos los recursos en la vía judicial, y que, por éste, se hubiera efectuado una acción u omisión que pudiera violar tales derechos. El amparo constitucional se configura así con «carácter extraordinario y suplementario de la tutela de los derechos fundamentales y libertades», como ya recordó el TC en sentencia de 15-11-1990. Por lo que se refiere a las relaciones entre los particulares y cuando no se cumplen los requisitos de salvaguarda de la libertad o los derechos exigidos por la Carta Magna, el TC mantiene que tal amparo «normalmente corresponde a los Jueces y Tribunales a los que el ordenamiento encomienda la tutela general de tales libertades y derechos» (S TC 18/1984 de 7 de febrero).

\section{El derecho a un proceso justo}

Cuenta Kafka ${ }^{35}$ que cuando K. va a casa del pintor Titorelli le encuentra pintando la figura de un Juez («en actitud de incorporarse con tono amenazador») y una figura alada que representaba a la Justicia; $\mathrm{K}$. le comenta que «la justicia debe estar inmóvil, pues de lo contrario la balanza oscila y no puede pesar con exactitud». No le faltaba razón al bueno de K., que se vio envuelto en un proceso con múltiples peripecias e insólitas resoluciones. Para que el ciudadano pueda estar tranquilo de que los jueces van a acertar debe tener, por lo menos, la intuición de que está sometido a todas las garantías que, como veremos más adelante, supongan una eficacia personal. En definitiva, para decirlo con palabras de Guasp ${ }^{36}$ y en términos comprensibles, cuando se «solicita la intervención del Juez, se formula con objeto de proteger un derecho subjetivo de que el solicitante es titular», sobre derechos que cree que han sido vulnerados. Pero tal como se ha venido transmitiendo de boca en boca, «tres cosas son menester para la justicia alcanzar: tener razón, saberla pedir y que te la quieran dar»; no es muy esperanzador el canto popular de dejar la decisión del «querer»al juzgador. Ya que éste no produce decisiones «personales» ni subjetivas, sino que tales decisiones son, por su propia naturaleza, objetivas. El

\footnotetext{
35 Franz KAFKA, El proceso, Edaf, Madrid, 1989, p. 222.

36 Jaime Guasp, Concepto y método del Derecho Procesal, Civitas, Madrid, 1997, p. 12.
} 
TC, en sentencia de 14-11-1994, se refiere a ello al insistir «en la importancia que en esta materia - salvaguarda de la neutralidad e imparcialidad - tienen las apariencias, pues va en ello la confianza que los tribunales de una sociedad democrática han de inspirar en los justiciables». Si las Leyes responden, siempre, de los aspectos tuteladores de los justiciables, hay alguna extraña razón — no siempre perceptible, pero sí cuantificable - por la que las encuestas de opinión sitúan a la justicia por debajo de los mínimos deseables en cuanto a eficacia y prestigio.

El ejercicio de los derechos ante los Tribunales a través del proceso, es para el «aprovechamiento o satisfacción de un interés»; si esto es así - que lo es - a nadie puede extrañar que cuando se desestima una pretensión o se condena a un justiciable se recele de la justeza de aquella decisión, ya que se trata de un «interés» que puede ser directa o indirectamente personal. Cuando los juzgadores acogen las subjetividades de las partes, las colocan en aquella balanza inmóvil de Titorelli, las convierten por el arte de juzgar en precisiones neutrales, sin contrapesos o medidas espúreas. Goldschmidt lo dijo muy claro: «La imparcialidad consiste en poner entre paréntesis todas las consideraciones subjetivas del juzgador; éste debe sumergirse en el objeto, ser objetivo, olvidarse de su propia personalidad».

La respuesta al interrogante de saber cuándo un proceso es justo no está exenta de demagogias, subjetividades tendenciosas o influencias mediáticas. Estas últimas pueden airear los casos más llamativos en los que se ven implicados personas de resonancia política o social, o las sentencias desorbitadas o anormales para dar pábulo a la opinión. Cada día son dictadas miles de resoluciones por jueces callados y eficaces, pero que -inevitablemente- se verán criticados por quien pierde un pleito o es condenado a penas creyendo ser inocente. Contestar a la pregunta de por dónde transita el proceso justo haciendo abstracción del «aprovechamiento» de los justiciables es la tarea de quien tiene en su poder la decisión de declarar tal justeza.

Lo que nosotros llamamos proceso no tiene una expresión unívoca en las normas procesales. Ni siquiera la $\mathrm{CE}$ alude a él con carácter correcto, pues si bien a las leyes las llama «de procedimiento», a su aplicación (oral) también la llama así, en lugar de proceso. El término tiene diversos remedos en las normas procesales. A veces se llama «juicio», otras «pleito» o «litigio», otra «cuestiones litigiosas» o «pretensiones», «asunto», «controversia», «causa», etc. Sea cual fuere la terminología aplicable, al justiciable lo que le preocupa es que su interés sea tratado en justicia, y para ello — sin entrar en doctrinas sobre la naturaleza del proceso-, pasa por los siguientes parámetros: 
A) Unicidad. Instar justicia o que la proclamación de un derecho ante otros se vea amparado no tiene ninguna otra vía posible que el proceso. Se ha recordado que «el Estado de Derecho es necesariamente un Estado de Justicia, en el sentido explícito de justicia judicial y no en cualquier otro más etéreo o evanescente» ${ }^{37}$. Sólo hay una justicia que responda al proceso, y sólo hay un proceso que responda a la justicia jurisdiccional. Otra cosa será acudir a la justicia social o a la distributiva a través de la convención colectiva de trabajo, o a las leyes fiscales, por ejemplo. Y, por otro lado, el proceso no se puede dividir ni entre varios juzgados ni en varios órdenes jurisdiccionales a la vez, pues lo que puede resolver uno excluye al otro, más que nada por la seguridad de que toda justicia debe estar impregnada.

B) Una vez instada la mediación de Juzgador, debe enterarse de las posturas de las partes - y sobre todo el conocimiento de los hechossino que su imparcialidad debe estar presidida por el principio audiatur et altera pars. Ser oído o tenido como parte comporta acceder a todas las actuaciones judiciales sin oscuridad ni detraimento de los actos procesales; en definitiva, como se dice en el artículo $24 \mathrm{CE}$, ser «informado», bajo la ya clásica norma de que nadie puede ser condenado, ni juzgado, sin ser oído.

C) Sobre la imparcialidad, baste decir que la neutralidad es una de las bases fundamentales del Estado de Derecho. La inmovilidad a que se refería Kafka al pintar a la justicia alada, cuando debía estar estática, quiere decir que no puede - el proceso- estar sometido a los vaivenes de decisiones ajenas a las partes y a la ley. El juez forma parte de la controversia, está ínsito en ella, pero no es una parte lateral sino una parte central inoscilante, con el ojo fijo en las posturas de los laterales pero ajeno a las miradas - a veces griteríos - de los que no son parte. Porque - comenta Aragoneses- «el proceso responde a una necesidad social, y la jurisdicción es una estructura para satisfacer tal necesidad» ${ }^{38}$. Si bien el proceso justo aparece invocado por los entes sociales o institucionales, no puede criticarse una decisión final de un Tribunal imparcial cuando las propias instituciones se han dado (para ellas) este modelo de procedimiento por el que discurre la pretensión procesal.

D) La garantía material de un proceso justo o de un «debido proceso» pasa por cumplirse todos los derechos a que se refiere al arículo $24 \mathrm{CE}$,

37 Eduardo García de Enterría, Democracia, Jueces..., Civitas, Madrid, 1995, p. 151.

38 Pedro Aragoneses Alonso, Proceso y Derecho Procesal, EDERSA, Madrid, 1997, p. 129. 
esto es, que todas las actuaciones cronográficas —o en su caso oralespasen por el cedazo garantista-procesal que se ampara en la Constitución y, por ende, por las normas de los procedimientos. Así —como veremos más adelante- la eficacia de un proceso justo pasa por posibilidad de comparecer ante los órganos judiciales, posibilidad de defensa, gratuidad de los órganos y la decisión final como culminación del amparo. Y no se trata de establecer una justicia personal o subjetiva, a pesar de que irremediablemente sean personas las que comparecen, sino que, como ya apuntaba Carnelutti, «el juicio sirve para establecer lo que es justo». Lo que nos lleva a concluir que el derecho a un proceso justo no ampara una pretensión injusta, pues la eficacia de los Tribunales no puede ir más allá de lo que la justicia le permite, sin extenderse en cuestiones caritativas o morales. 


\section{EL JUEZ COMO PODER INDEPENDIENTE}

\section{Antecedentes}

Una propuesta de estudio tan actual que o bien pueden quedar obsoletos estos planteamientos en un periodo corto o llevarnos a un replanteamiento, pero con la misma sustancia que tenía hace más de un siglo, cuando la Ley Orgánica del Poder Judicial de 1870 proclamaba:

Conveniente es que los representantes del Poder Judicial se hallen alejados del terreno de la política activa, no tomando parte en sus ardientes luchas... deben evitar que el ánimo aparezca turbado por las resueltas pasiones de los partidos que aspiran a influir de una manera directa en la gobernación del Estado ${ }^{1}$

Tan sabia propuesta debería ser tenida en cuenta y figurar en el frontispicio de la formación y decisiones del Poder Judicial. Esta era una independencia política, alejada de toda injerencia de partidos, pero de una forma amplia y extensa no sólo desde el alejamiento de afiliación, sino de la influencia exógena de presiones, propuestas electorales tan ajena a la propia independencia de quien juzga y que está sometido, a veces, a la institución - por otra parte respetable - de la ideología deformadora del equilibrio arbitral.

En la primera Constitución de 1812, se establecía en su Título V «De los Tribunales y de la Administración de Justicia en lo Civil y en lo Criminal», en el cual se contenía una novedosa — para aquella época- regulación de la justicia y de los Tribunales, cuya función exclusiva era «juzgar y hacer ejecutar lo juzgado», y los magistrados y jueces «no podrán ser depuestos de sus destinos».

La denominada Constitución de Cánovas para la Monarquía restaurada, de 1876, establecía en su Título IX la regulación «De la Administración de Justicia», siguiendo la idea anterior de no poder ejercer otras funciones que juzgar, siendo los jueces inamovibles y responsables.

La Constitución republicana de 1931, como es obvio, cambia el espíritu y la filosofía de las anteriores constituciones, bajo el cariz político

1 Y seguía diciendo la exposición de motivos de aquella ley: «El Juez o el Magistrado que toma parte activa en determinadas candidaturas, y el que en sus manifestaciones públicas se declara partidario intransigente de una idea política, por más que a la puerta del Tribunal se despoje de su afección y de sus odios, no será creído por el que tenga que comparecer ante él en demanda de justicia cuando su adversario pertenezca al bando político en que ese juez se haya afiliado». 
y revolucionario de la época, como se aprecia en su artículo primero: «España es una República democrática de trabajadores de toda clase». Y por lo que respecta al apartado de la Justicia, en el artículo 94, proclama que «los jueces son independientes en su función. Sólo están sometidos a la ley». Se refiere también a las incapacidades e incompatibilidades, con la advertencia de que el ejercicio de la magistratura «durará diez años». Se establece la inamovilidad, el traslado y la responsabilidad civil y criminal de los jueces.

Durante el régimen del general Franco, la Ley Orgánica del Estado establecía en su artículo 29 que «la Justicia gozará de completa independencia», «administrada por Jueces y Magistrados, inamovibles y responsables con arreglo a la ley». Salvando las distancias sobre la forma y estructura del Estado, la redacción es, en algunos aspectos, parecida a la del artículo 117 de la Constitución actual. No obstante hemos de señalar que no se conciliaba muy bien aquel artículo 29 sobre la independencia del poder judicial con el sistema institucional, que respondía a «unidad de poder y coordinación de funciones». Por eso, nos parece criticable desde la comparabilidad de sistemas —aquél totalitario, éste actual democrático- que los miembros del Poder Judicial sean nombrados - todos- a propuesta de otros Poderes, lo que en definitiva unifica el poder para que lo ejerza el partido más votado o la ideología al uso.

En todas las épocas - y con más acento en las revolucionarias o conflictivas - han tratado los políticos de acceder al control de la justicia. En los momentos anteriores y en plena guerra civil española, pedía el Frente Popular la independencia de la justicia pero, naturalmente, «una vez reorganizada» de acuerdo con los postulados de su ideología. Los regímenes totalitarios piden - tal como fue constituido en la Rusia de 1921 - una «autoridad absoluta», bajo el ejercicio y control del partido en las distintas formas de vida: burocracia, prensa, y la abolición de «todos los límites legales impuestos al poder» ${ }^{2}$.

2 Ricardo Lowenthal, «La URSS modelo de estados totalitarios», en Rusia encuentra su nuevo espíritu, Madrid, 1967, N y C, p. 89. Las cuatro características que definen al Estado totalitario son, para el autor: la autoridad absoluta del partido dirigente sobre el Estado; la segunda, el ejercicio del partido sobre todas las formas de vida, con una «red de organizaciones que limitan a los individuos desde que nacen hasta que mueren» (sic!); la tercera, «autoridad absoluta del régimen sobre los órganos de difusión, de la prensa y otras mass media a la literatura, el arte, la educación»; y la cuarta, la posibilidad para el Estado de utilizar medios arbitrarios o terroristas, cuando lo juzgue conveniente para el cumplimiento de los deseos del régimen. 
Durante la guerra de 1936, ambos bandos siguieron un sistema de depuración dentro del ámbito de la judicatura. La idea de formar un juez «republicano» que propagó un bando, fue recogida por la otra parte como la formación de un juez «nacional», pasada una primera etapa de totalitarismo de los vencedores de la guerra civil. Como recuerda Montero Aroca ${ }^{3}$ «después de este intento de lograr un «juez nacional», las aguas volvieron al cauce de la «politización».

A pesar de la declaración de independencia de todas las Constituciones o Leyes, lo cierto es que la judicatura ha sido moneda de cambio en los cambalaches políticos, el poder judicial apetecido por las ideologías a través de los partidos políticos y las decisiones judiciales mediatizadas, a veces, por el impacto liberal de una combinación demagógica y utópica.

Si se ha criticado que en el régimen de Franco el Presidente del Tribunal Supremo fuera nombrado entre «juristas españoles de reconocido prestigio», ahora se denuesta la transacción sobre nombres ataviados con determinado ropaje ideológico y que pudieran influir en las decisiones de nombramientos en el Tribunal Supremo, en las Audiencias Provinciales o en los expedientes disciplinarios que pudieran alejarse del reconocido prestigio para navegar por el de reconocida adscripción.

Si se habla tanto de la justicia, no es porque las decisiones judiciales interesen al ciudadano, sino que se habla porque su funcionamiento deja mucho que desear para llegar a lo que la Constitución llama Estado Democrático y Social de Derecho. Si a veces los ciudadanos no creen que los jueces son independientes, no es porque lo palpen en sus propias carnes sino porque respiran la noticia de trifulcas entre el poder ejecutivo y el judicial, entre los propios jueces, entre el jurado popular y los jueces; y, dentro del entramado de las normas judiciales ininteligibles, oyen y ven lo que les dicen los medios de comunicación, ávidos de noticias atronadoras sobre el comportamiento de una determinada persona o la eficacia de una resolución judicial equivocada.

El juez se ve así rodeado, observado, casi diríamos que espiado para caer sobre él al más mínimo desliz. No cabe duda que si la justicia emana del pueblo y se administra en nombre del Rey, el juzgador se debe a un doble compromiso - ya no es independiente en el sentido estricto-: por un lado se debe a la Corona y no puede ser un «juez republicano», ni tampoco un «juez popular» (ni populachero), pues se

3 Juan Montero ArocA, Independencia y responsabilidad del Juez, Civitas, Madrid, 1990, p. 69. 
administra en nombre del pueblo en el sentido de organización social «del que emanan los poderes del Estado». Es decir, que su justicia es el desideratum de un crisol que es la organización del Estado. Cuando el Juez se viste la toga lleva sobre sus hombros un poder real y un poder social. Ni más ni menos que una dignidad aristocrática y un mandato del pueblo. Difícil independencia ésta de cumplir dos compromisos y alejarse los lodos que pueden degenerar en demagogia o ser tentados por la autocracia.

\section{La independencia como término difuso}

La palabra independencia o independiente puede aplicarse a las cosas, a las posiciones, a los Estados, a las economías, a los vehículos; por fin, a los cargos o personas. Para aplicarla a la función judicial, al poder judicial o a la judicatura no sólo es necesario acudir a las normas que los puedan regular, sino que la realidad de los entornos hacen imposible que se defina o delimite. Tal limitación, como veremos, se hace poco menos que imposible. Y como recordaba Henry Sumner ${ }^{4}$ en una obra que glosaba el Derecho antiguo: «las ideas rudimentarias del derecho son para el jurisconsulto lo que las capas primitivas de la tierra para el geólogo, en cuanto contienen en embrión todas las formas que el derecho ha tomado posteriormente» (refiriéndose a estudiar los conceptos jurídicos a través de los poemas, bajo las palabras de Themis y Themistas). Esto es, que no podemos analizar un concepto desde la lectura legal si la realidad nos separa cada día de esta legalidad. Decir que los jueces son independientes, sometidos a la ley y al Derecho, no es decir nada para el ciudadano de a pie, aunque para el profesional de la justicia su lectura tenga unas connotaciones deontológicas o de estructuralismo profesional.

Se ha dicho que «el concepto de independencia es, ante todo, una noción relacional» ${ }^{5}$. Creemos que ello es cierto, pero también que es un concepto jurídico indeterminado, una relación comparativa, una obligación y una secuencia profesional.

A) Es un concepto jurídico indeterminado porque lo que caracteriza a tal concepto es una indeterminación absoluta y concreta. Más bien

\footnotetext{
${ }^{4}$ Henry Sumner Maine, El Derecho antiguo, Madrid, 1893, p. 14, facsímil editado por Civitas en 1993.

5 Juan F. LóPez Aguilar, La justicia y sus problemas en la Constitución. Tecnos, Madrid, p. 114.
} 
la independencia, como veremos, se define en cada momento justo y preciso. Podemos aseverar que tal definición en la ley es ambigua y su aplicación es concreta. Ahora bien, si como reconoció García de Enterría $^{6}$ en uno de los primeros estudios sobre la materia, «el concepto jurídico indeterminado se cumple o no se cumple» nos encontramos con una traba - más bien maraña- de circunstancias en las que tal situación concreta puede ser variada y «no más que una» (como argumenta Enterría), pues si bien es cierto que en los conceptos jurídicos indeterminados sólo hay una solución entre varias o la contraria, esto es, o hay conculcación del orden público o no, o la casa es ruinosa o no, la temeridad existe o no, el concepto de independencia puede variarse o verse desde diferentes ópticas. Así se es independiente respecto de las presiones familiares, de la injerencia de los superiores, pero se depende - aunque sea subconscientemente — de la adscripción ideológica o de la presión ambiental.

B) Es un concepto comparativo, porque se entremezcla con otras realidades jurídicas y sociales. Así las decisiones del juzgador deben ir acordes con la interpretación sobre determinada norma que efectúa el Tribunal Supremo al «interpretar la ley, la costumbre y los principios generales del derecho (art. 1.6 del Código (Civil). Otras veces no tiene más remedio que aplicar la realidad social, ordenado por el artículo 3.1 del CC. Ya nos surgen, de inmediato, aspectos que erosionan la independencia volitiva o intelectual de quien juzga y que mira de soslayo la decisión de otros juzgadores o la de una presión social que lo hace vulnerable a una posible idea preconcebida del concepto de justicia. Nace, sin querer y al hilo de la disertación, la independencia comparativa. Unas veces se es independiente in puribus y otras mediatizado intelectualmente por otras decisiones, otras ideologías, otros poderes, en fin. A su derredor, para ser justamente independiente, deben situarse el resto de los estamentos, las instituciones, los partidos, los sindicatos, las asociaciones, todo el entramado social, en fin, bajo la cultura de la justicia cuyo emblema se dibuja por ser justo y no arbitrario, independiente y no mediatizado. Las palabras de Thering acuden prestas a nuestra postura: «No, no basta para que el derecho y la justicia florezcan en un país, que el juez esté siempre dispuesto a ceñir la toga, y que la policía esté dispuesta a desplegar a sus agentes; es preciso aún que cada uno contribuya por su parte a esta gran obra, porque todo hombre tiene el deber de pisotear, cuando llega la ocasión, la cabeza de esa

6 Eduardo García de EnTerría, La lucha contra las inmunidades del poder, Civitas, Madrid, 1974, p. 36. 
víbora que se llama la arbitrariedad y la ilegalidad» ${ }^{7}$. Hay todo un entramado social que recorre la vida del juez, unas visiones ajenas a su decisión, unas opiniones que lo comparan con otras actitudes e ideas. El Juzgador no es ajeno a estos niveles de comparación. Se le premia con loables artículos periodísticos, o le denigran e insultan abogados, dirigentes políticos o periodistas, según tercie o según sus decisiones sean favorables a los intereses de unos o de otros. Se compara con otros jueces, con otras épocas, con otras decisiones.

El juez mismo, a veces, se pregunta si su independencia se tambalea, no tiene cimientos estables, si su intelecto padecerá ceguera o si su decisión refleja fielmente el concepto de justicia. Compara su postura, se analiza, en ocasiones sufre en solitario y su independencia se desmorona.

C) Obligacional. El mandato constitucional (art. 114) configura al Poder Judicial como el compuesto por Jueces y Magistrados independientes, concepto y prerrogativa que obliga a respetar a todos los españoles, al aprobar el pueblo y mandar que «guarden y hagan guardar» la Constitución. La independencia, por tanto, forma parte de las prerrogativas del poder judicial integrado por los Jueces y Magistrados. De tal suerte que si en el artículo $1 .^{\circ}$ de la Ley Orgánica del Poder Judicial se proclama que los Jueces y Magistrados son integrantes del Poder Judicial, y aquellos son independientes, éste también lo es por subsunción de los unos en el otro. Por ello decimos que es una cuestión obligacional para todos, sean poder en el sentido constitucional o sociológico. De manera que los otros poderes están obligados a preservar al Judicial en su independencia. No sólo es obligado para los jueces a los que se les ha dotado de inmunidad, pero también de responsabilidad, sino también para los demás poderes que conforman el Estado de Derecho. Así la ley debe preservar a los jueces en su independencia, la Administración velar por lo que figura en el Título II de la LOPJ, y los poderes sociológicos (medios de comunicación — cuarto poder-, las manifestaciones sociales — quinto poder-, los partidos políticos, la Iglesia, etc.) cumplir el mandato constitucional desarrollado por la Ley. Si, como dice Ihering ${ }^{8}$, el hombre lucha por defender su derecho personal, su acción debe trascender su personalidad. Los derechos personales, todos, pasan al ejercerlos por la obligación de preservar a la justicia en una independencia que haga posible la eficacia de

7 R. Von Ihering, La lucha por el Derecho, Porrúa, Mexico, 1989, p. 70. Edición Facsímil, Madrid, 1881.

8 R. VON IHERING, op. cit., pág. 67. 
dejar inamovible el fiel de la balanza. La independencia se traslada como obligación a otras esferas ajenas a la justicia — pero protegidas por ella-.

D) Profesional. La independencia judicial es típicamente profesional; se vincula a la labor, al trabajo, a las obligaciones laborales; la independencia debe estar presente en la categoría profesional, en la decisión de cada resolución, en la conducta, en fin. Se mantiene - so pena de las influencias que veremos - con vocación de permanencia como un elemento fundamental — sin él carece de sentido la justicia$\mathrm{y}$ responde al ars resistentiae, como pieza que engrana las ruedas dentadas unísonas y fieles a la ética, muro perenne en que chocan las insinuaciones políticas o las tendencias prevaricadoras. Es, como se ha dicho $^{9}$, «una prerrogativa eminentemente funcional». Pero no sólo es prerrogativa, es decir, no se ejerce como derecho proteccionista, sino que se vincula a la profesión como deber de permanecer incólumes ante los vaivenes de la sicología o la política. Todas las profesiones tienen sus derechos y deberes, sus códigos deontológicos. Toda colegiación -y más entre los operadores jurídicos - se rige por derechos y prerrogativas, consideraciones y tratamientos, pero como contrapartida existen los deberes de su actividad, su responsabilidad ante el cliente, el enfermo o el contratista. Pero ninguna profesión es observada con más tesón microscópico que la de Juez. Y si ya tenía que esmerarse en su pulcritud de acción, sin contrapartida premial, a ello se añadió la desaparición del Código Penal del delito de desacato, aunque se incorporan al CP de 1995 los delitos de «obstrucción a la Justicia y la deslealtad profesional».

\section{El sometimiento a la Ley}

El punto primero del artículo $117 \mathrm{CE}$ compendia y envuelve a las notas que caracterizan el Poder Judicial (independientes, inamovibles y responsables) y que quedan circunscritas al «sometimiento únicamente al imperio de la ley», cuya expresividad activa queda contenida en el artículo 5 de la LOPJ ordenando a los jueces que interpreten las Leyes conforme a la Constitución. De esta forma, el juez crea su propia independencia, que perjudica, en ciertos aspectos, a la unificación del Derecho. El mandato de que los jueces «interpretarán y aplicarán las leyes y los reglamentos según los preceptos y principios constitucionales»

\footnotetext{
9 Juan F. LóPEZ Aguilar, op. cit., p. 114.
} 
deja un portillo abierto hacia la decisión personal. Porque no hay otros principios inalterables y claros que los fundamentales y las libertades públicas. Lo demás son, a veces, programación genérica que se somete a múltiples decisiones, dependiendo del talante de los jueces (así conceptos tan grises como «defensas de la productividad»-artículo 38 $\mathrm{CE}$ - Servicios esenciales —artículo 37-, «prestaciones sociales suficientes» —artículo 40—, «acceso a la cultura» —artículo 44-, «disfrute del medio ambiente» - artículo 45-, «derecho a una vivienda digna», etc.

Según el artículo 5.1 de la LOPJ, los jueces deben juzgar conforme a los principios constitucionales, los que deben presidir toda ley. Ahora bien, se le deja una puerta abierta a quien juzga sobre la posibilidad de decidir en un caso concreto para que interprete la ley según la Constitución. Ello encierra no pocos peligros, ya que pueden darse tantas soluciones como talantes o formación de quien juzga. Muchas veces, bajo la sombrilla - casi siempre caduca, obsoleta y antigua - del progresismo se conculcan los principios más elementales del sometimiento a la ley, dejando a la norma hecha harapos ${ }^{10}$.

Si se llega a esta conclusión amplia en cuya manga cabe toda interpretación exhaustiva de la Ley, llegaríamos a reemplazar la decisión judicial por la legislativa. La labor de los jueces no es esa - aunque la del Poder Judicial sea informar, aconsejar o dictaminar sobre leyes-, los jueces «no gobiernan ni desplazan a los legisladores», dice Gargarella ${ }^{11}$, añadiendo que existen dificultades para la interpretación de las leyes por parte del poder judicial. A veces cuando al legislativo no le convence esa interpretación cambia la norma. Aquí surge de inmediato un dilema. $\mathrm{O}$ los jueces se hallan alejados de la realidad social o los legisladores no han conectado con el pueblo (con su electorado, al fin). Difícil tarea que deben analizar los sociólogos. La tarea de los jueces es así indisputable (Gargarella). Si el poder legislativo se deja llevar por el grupo más hablador, la pancarta más constante o los gritos de las minorías para dictar las leyes, el juzgador debe tener presente la realidad social, el espíritu y la finalidad de las leyes. Precepto tan amplio y escurridizo que ha sido saco de no pocas arbitrariedades, bajo la capa de una realidad ficticia, de escasa implantación o fugaces situaciones. El juez no puede crear el Derecho que le apetezca ni ir más allá de la Constitución sino que debe exprimir sus derechos o deberes en

10 Valeriano Hernández MARTín expone algunos en su monografía Independencia del Juez y desorganización judicial. Civitas, Madrid, 1991, pp. 117 y siguientes.

11 Roberto Gargarella, La justicia frente al gobierno, Ariel, Barcelona, 1996, pp. 79, 80. 
lugar de hincharlos sobre un aire que no tiene consistencia jurídica y se desmorona al menor pinchazo.

Lo que se denomina directriz sociológica de la norma no es otra cosa que la interpretación coetánea a que se refiere el artículo 3 del $\mathrm{CC}^{12}$. Es evidente que tan sabia decisión no puede dar una luz a la oscura o antigua norma. Una luz, por supuesto que no puede ampliarse por entender que esa realidad social no está aislada, sino que, como bien se dice en el citado artículo $3 \mathrm{CC}$, debe estar dentro del contexto los antecedentes históricos. Esto es así porque las circunstancias y situaciones sociales en las que se produce el nacimiento - su proposición, discusión o desarrollo parlamentario- de una ley, están presididas por movimientos ideológicos, transacciones políticas, influencias o presiones; y pasadas aquellas situaciones queda la letra que debe aplicarse en cada momento posterior. «El intérprete debe buscar la norma jurídica no sólo en la letra de la ley sino en los hechos sociales que le rodean, en las ideas económicas, morales y políticas que hayan encontrado su expresión en normas posteriores y actuales, pues esta concreción objetiva de cambio es la garantía contra la apreciación puramente subjetiva del intérprete» ${ }^{13}$. Tal propuesta no puede entenderse como una solución para una interpretación correcta, constante y objetiva de la Ley. La única garantía que permite la LOPJ (art. 5) es el sometimiento a los principios constitucionales, esto es, los valores superiores del ordenamiento jurídico. Ahora bien, tal valor amplio, conceptual, filosófico y prometedor no puede tener un encuentro distinto de los intérpretes. $\mathrm{Ni}$ siquiera el Tribunal Constitucional puede dar pautas sobre ellos dependiendo de su extracción ideológica, profesoral, académica o judicial.

El Derecho ha de mantenerse siempre vivo bajo la premisa interpretativa, pero ello no permite el cambio, como se cambia de partido o de dirigentes. No se trata, como algunos argumentan, de aplicar una ley permisiva, ni de sociologizar el Derecho, sino de enlazar la realidad con la historia jurídica. Tampoco se pretende respaldar con la justicia cualquier hecho social, sino que el espíritu de la norma no sea una entelequia pasado el tiempo de su promulgación. Porque a los jueces les

12 Isidoro Alvarez SaCristán. Artículo completo en el Boletín del Iltre. Colegio de Abogados de Madrid, n. ${ }^{\circ}$ 5/1987, bajo el título «La interpretación de la norma conforme a la realidad social».

13 Manuel Batle VÁzQuez. Comentarios a las Leyes Civiles, tomo I, p. 84. Tal postura puede tener el peligro de olvidarse de la ley para aplicar la realidad social y someter la decisión del juzgador a la equidad, cuya aplicación esté proscrita en el CC (art. 3.2), al poder aplicarla cuando la ley lo permita. Lo que denomina Batle la «garantía de cambio», nos acerca más al uso alternativo del derecho que «al sometimiento de la ley». 
tiene sometido el poder legislativo a toda una variación constante de leyes y situaciones que no responden a la realidad social ${ }^{14}$, sino únicamente a la presión de un grupo o de una organización sin el correspondiente respaldo social. Es el prurito de salir en la foto o de ser innovador de algo que nadie ha querido innovar.

Como dice la exposición de motivos de la reforma del Título Preliminar del CC de 1974, esta interpretación y su empleo es «ciertamente muy delicado», pues se trata de una adaptación que no está exenta de subjetivismos jurídicos. Nosotros creemos que una interpretación sociológica no puede hacerse extramuros de la histórica, de la lógica, de la axiológica, de la literal, de la finalista; porque la llamada directriz sociológica no puede tomarse aisladamente so pretexto de los vaivenes de los hechos sociales, sino que la prudencia interpretativa debe ir unida a una constatación real de las decisiones judiciales si no van en contra del devenir vivencial de los justiciables.

Claro que ello nos lleva de la mano a una situación tal que si no es tomada por jueces equilibrados formados y responsables se tornará su actuación en arbitraria y permisiva. Bien es cierto que normas antiguas, aunque vigentes, serían risibles en su aplicación si ahora se invocaran. El concepto de orden o desorden público no es igual ahora que hace 30 años.

En definitiva, el Derecho es contestado por la sociedad, al contrario que en épocas pasadas, en que el Derecho acudía al hecho para juridificarlo. Ello plantea ${ }^{15}$ la comparación entre la legalidad real y legalidad ideal. Lo cual implica que en algunos campos del Derecho las reformas sean constantes y permanentes (Derecho laboral). El espíritu de tal aplicación no son sólo los valores permanentes, sino la ponderación.

\section{Independencia e interpretación}

El juez bajo el manto amparador de la independencia no es un sujeto que pueda aplicar el precepto de la norma con preceptos obsoletos o rebuscados para adornar su decisión, pues suele ocurrir que cuanto

14 Un claro ejemplo de esta situación es la Ley del Jurado, pedida por una exigua Asociación para el Jurado, la idea de un equipo ministerial y la rápida aprobación por las Cortes sin el respaldo de la sociedad, que según todas las encuestas ni lo deseaba, ni lo pedía, ni lo creía necesario. Con resultados nefastos en los casos más sonados: absolución de una persona que mató a dos policías autonómicos, absolución de un marido que mató a su esposa, etc. El Jurado ha sustituido a un juez independiente sin gozar de una independencia sociológica o ideológica.

15 Olabuénaga, Sociología y Derecho. Materiales de Sociología Jurídica, Gobierno Vasco, Vitoria, 1984, p. 13. 
más oscura es la redacción, más subjetiva es la decisión. Hacer la justicia de hoy, actual y encomiable, es hacerla al aplicar la norma vigente. Para nosotros bajo un triple aspecto: responsabilidad profesional, motivación lógico-jurídica y entorno sociológico. El juez no es, por tanto, independiente en el sentido hermenéutico de la palabra; es, sí, independiente en cuanto es $-\mathrm{o}$ debe ser- libre de condicionamientos jurídicos o políticos, libre de presiones extrajudiciales; la única presión a la que debe estar sometido es la justicia derivada de la interpretación garantista-Constitucional de la Ley. Esta situación no es aislada - por ello difícil—, ya que hay que indagar su verdadero espíritu, su función social. Está inmerso en una cuádruple dimensión: Juez-justiciable-ley-resolución. Conexión que se produce con el entorno social. Pues si los jueces interpretan la norma distanciados de la sociedad no se produce justicia, porque, además de desconectar al juez de esa relación apuntada, desequilibran el cuerpo social, irritan al justiciable y se ponen en contra de la opinión sensata. Otras veces, el juez, por exceso, aplica la realidad social, pasajera, sin tener en cuenta que la realidad social no puede tomarse por el hoy y por el mañana. No puede aplicar la ideología dominante ni la influencia del político de turno, ni dejarse influir por los impulsos ideológicos ni por la formación política o religiosa. Creer que tal interpretación es aplicar la norma bajo las directrices de un partido es, además de desviarse de la juridicidad que debe presidir la decisión profesional, un desacato al pueblo, del cual, no lo olvidemos, emana la justicia.

\section{La contaminación política}

No hay que olvidar, sino mejor tener presente siempre, que las leyes las construyen los políticos - Poder legislativo- y que otro Poder, influido y nombrado por políticos, acude a la relación entre los jueces, nombra a los Magistrados del Tribunal Supremo y dictamina sobre las leyes. De tal suerte que el juez de a pie, por mucha preferencia que tenga de dar juridicidad a su conducta, de prestar su inteligencia a la razón y a la justicia, se ve mediatizado por la política, esto es, por la ideología más intrigante. Porque «el método de estudiar la influencia de los principios jurídicos consiste para Esser en examinar la conducta de los jueces» ${ }^{15 \mathrm{bis}}$. Una conducta que, al decir

15bis Citado por Angel SÁNCHEZ DE LA TORRE, Textos y documentos sobre Derecho natural. Madrid, 1967, p. 338. 
de Alexy ${ }^{16}$, debe tener presente para acceder al Derecho la mezcla de la descripción del Derecho vigente, el análisis conceptual y las propuestas de los casos problemáticos. De ahí que el juzgador tiene dos caminos: a) el recto, acompañado de vicisitudes no siempre coherentes, apoyado por el cayado de la inteligencia y la razón, la rectitud del saber, la interpretación honrada lejos de los vicios de influencias exógenas al derecho; o b) el tortuoso de la alabanza, la loa de los políticos, el surco fácil de la misericordia o de la falsa caridad, en definitiva, haciendo un uso alternativo del derecho.

Tal concepto tuvo fortuna entre las tendencias marxistas y ha sido denunciado por la intelectualidad correcta y de progreso jurídico, entre otros por García de Enterría, Zorrilla, etc. ${ }^{17}$ Tiene su génesis en la idea de que los jueces pueden aplicar cualquier interpretación de las leyes desde la perspectiva de la ideología. Para el soviético Vyshinsky, «la norma nace como pura voluntad política, expresión, por tanto, de un latente autoritarismo» ${ }^{18}$. Explica tal teoría Cerroni: «Se comprende que con este procedimiento la utilización de las técnicas jurídicas se convierta, precisamente, en una mera utilización instrumental que encuentra su razón de ser no ya en la norma y en la lógica del ordenamiento, sino en la voluntad política que lo sostiene» ${ }^{19}$. Este tipo de actuación entre la política y el Derecho, es para las ideas marxistas -algunos las llaman de izquierdas y progresistas (!) — un campo amplio flexible cuando actúan en regímenes democráticos y una férrea disciplina interpretativa cuando tienen que juzgar en los regímenes totalitarios.

Esta influencia italiana tuvo éxito en nuestro país, y se publica por tres veces un artículo de Pietro Barcellona ${ }^{20}$ argumentando que se debe ligar el Derecho a la política porque son dos caras de la misma moneda o la «utilización instrumental del derecho para conseguir

16 Robert AleXY, Teoría de la argumentación jurídica. Centro de Estudios Constitucionales, Madrid, 1989, p. 241.

17 Eduardo García de EnTERría, El derecho, la Ley y el Juez, Civitas, Madrid, 1997, Manuel M. ${ }^{a}$ Zorrilla RuIZ, Teoría del Derecho, Deusto, Bilbao 1997.

18 J.A. VYSHINSKY, cit. por Umberto CERRONI, El pensamiento jurídico soviético. EDICUSA, Madrid, 1977, p. 96.

19 U. CERRONI, op. cit., p. 97. «Mientras por un lado la norma jurídica pierde su conexión orgánica... la ley debe modelarse en su ejecución y aplicación a las exigencias de la política tal como vienen entendidas por el órgano político.» Como se aprecia, el juez que no lo haga así será depurado. Pero en un régimen democrático estos jueces son libres de actuar, aunque se alejen de toda norma ético-jurídica y se alejen de la realidad social.

20 Pietro Barcellona, La formación del jurista, Civitas, 1977, 1983, 1988. Madrid. 
resultados políticos», pues para el autor «la realidad social es una fórmula vacía». Varias son las voces que dentro del partido comunista o sus afines se alzaron para transmitir esta idea a fin de crear un juez «capaz de expresar una sensibilidad diferente» (¿diferente a qué?) para «mediar en clave progresista en los conflictos sociales»20bis. Para los promotores de esas ideas los demás eran reaccionarios, conservadores, de derechas. Como se ve, además de llevar a la justicia por los derroteros del siglo XIX, dividiendo a la sociedad en derechas e izquierdas, alojaban términos extrajudiciales —es decir, políticos o sociológicos - en lugar de hacer una distinción entre sabios y adocenados, intelectuales y funcionarios, eficaces o indolentes, independientes o vasallos.

Bien claro dejó dicho Vishinsky que «la conciencia jurídica socialista del juez» corrige la aplicación de la ley. Desde esta perspectiva no hace falta que el Estado sea totalitario, basta que lo sean los que interpretan las leyes para «adaptarlas» a su ideología, utilizando la máquina estatal — como diría Lowenthal ${ }^{21}$ — sin límites legales.

Tal postura rompe de frente con el principio de independencia. El artículo 117 de nuestra Constitución —como se dejó entrever ya en $1978^{22}$ - al comentarla, fue contestado por «los juristas de inspiración marxista» al decir que «ni es neutral el Derecho ni, por consiguiente, en su aplicación cabe un ejercicio de independencia ideológica. En definitiva, razona Oscar Alzaga ${ }^{23}$ «desde determinadas actitudes altamente politizadas, se pretende trocar el tradicional sentido de la independencia de la Justicia, para defender un ejercicio de la función jurisdiccional en base al denominado uso alternativo del Derecho, en que el sometimiento a la Ley queda tamizado por la indicada interpretación politizada del Derecho a aplicar». El principio de Justicia, como dice Cicerón, es no sólo «dar a cada uno lo suyo» sino con la «grandeza y firmeza de un ánimo excelso e invencible».

Para dar mucha más claridad a la tergiversación que hace la doctrina - caduca ya- marxista, y desenmascarar la ocultación de una verdadera justicia por el ropaje de ese uso alternativo del derecho, alternativo y por ello exógeno al propio derecho, actualmente se le ha apellidado - como no podía ser de otra manera- como uso divergente

20bis Perfecto ANDRÉs IBÁÑEZ, Justicia/Conflicto, Tecnos, Madrid, 1988, p. 26.

21 Richard Lowenthal, «La URSS modelo de Estados totalitarios». En Rusia encuentra de nuevo su espíritu, N y C, Madrid, 1967, p. 115.

22 Oscar Alzaga, La Constitución Española de 1978, Foro, Madrid, 1978, p. 716.

23 Idem. 
del Derecho ${ }^{24}$. Efectivamente, el acierto del término viene a responder lo que se quiere transformar, porque divergir es estar dos cosas cada vez más lejos una de otra ${ }^{25}$ y es así como esta pretendida alternancia de la exigencia de la justicia se aleja cada vez más de ella, para entroncarse en las apetencias circunspectas de la ideología o, lo que es lo mismo, de los personalismos. Alejados, por propia definición, del acto jurídico-político, de la vida del Derecho, lo convierten - como acertadamente aduce Zorrilla ${ }^{26}$ - en una «aplicación subversiva» del Derecho. Con una táctica oculta revolucionaria, al uso de los grupos extraparlamentarios, lo que no se logra por el método de las urnas, de la acción parlamentaria, se pretende por la divergencia interpretativa de las leyes. Hay miles de ejemplos sobre las decisiones judiciales que explican esta tendencia. La sociedad se muestra perpleja ante tales decisiones, creyendo que es una opinión de todo el entramado judicial, sin saber que tal uso es una contribución de «consignas políticas».

Como se puede comprender, esta actitud judicial no es democrática sino totalitaria, ya que no sólo se diverge del legislador, sino que hace uso de lo legislado para ponerlo al servicio de la personalidad ideológica. Lo resume de una manera perfecta Zorrilla: «La esencia del uso divergente consiste en servirse de los valores invocados - relativos a orientaciones o normas constitucionales o de amplio espectro cultural- para ensanchar el ámbito de ciertos preceptos jurídicos y comprimir, si ello procede, la aplicación de otros, según sus soluciones se condigan o no con la promoción y defensa de los nuevos estados de cosas que aguardan un tratamiento adecuado a las circunstancias en que cobran vida» ${ }^{27}$.

Volviendo a la interpretación, si se hace uso alternativo no se está aplicando la ley en el sentido de justicia, de equidad, de aplicación, en suma, del principio de garantía constitucional. Y no es posible, como se ha dicho ${ }^{28}$, convertir al juez en un «asidero», cuando «la Ley ha perdido

24 Manuel María Zorrilla Ruiz, Teoría del Derecho, con Francisco Lledó, Deusto, Bilbao, 1997, pp. 569 y 570. «A esta técnica contribuyen consignas políticas que, además de utilizarla para abordar cuestiones técnico-jurídicas, promueven transformaciones sociales urgentes y especulares. El uso divergente surge a partir de circunstancias propias de la comunera política y propugna una actitud de resistencia cuyo triunfo augura el desmoronamiento de un Derecho - contra el que se combate- llamado a correr la más infortunada de las suertes... Está al servicio de compromisos radicales.»

25 Diccionario de María Moliner.

26 Idem nota 24.

27 M.M. ZoRrilla, op. cit., p. 570.

28 José Gabaldón, Control democrático del Poder Judicial. Poder Judicial XI, Madrid, 1986 , p. 85. 
su prestigio». Por ese camino, se convierte el juez en decisor sobre la eficacia en cada caso de una determinada norma. Lo que vale para unos casos no vale para otros. Como ya hemos dicho antes, la Ley no puede depender $«$ del talante personal de sus aplicadores» ${ }^{29}$, pues la seguridad jurídica se vería, así, conculcada. Bien es cierto que se pueden producir decisiones judiciales de distinto signo dependiendo del Tribunal o del juzgador de turno, pero ello se enmarca más en el principio de independencia que en el de arbitrariedad. Lo que queremos decir es que si esas divergencias se amparan precisamente en una interpretación jurídica de las normas y sobre el amparo constitucional de sus valores, nada impide - y una uniformidad devendría en otras connotaciones- que se den resoluciones distintas. Pero si tales divergencias se alejan de la vocación constitucional, del espíritu y de la mens legislatoris, con una clara aplicación ideológica, se está sirviendo, ya no al pueblo, a la justicia, sino a un fin extrajurídico, por lo que tales decisiones deben ser expulsadas de la jurisprudencia.

\section{La independencia sociológica}

Si la influencia política es decisiva para «contaminar» la aplicación de la ley, anteponiendo la ideología a la objetividad jurídica, otros factores sociales vienen a empañar la serena postura que ha de mantener el juzgador. Porque no es esta la realidad social a que nos hemos referido más arriba sino la irrealidad momentánea que presiona a través de la prensa, asociaciones, loobys más o menos enmascarados, sindicatos, etc.

A la prensa se le ha llamado el cuarto poder, los mass media que influyen en la opinión de la sociedad — de la que los jueces forman parte - que influye en la opinión de los jurados, de los políticos, de los votantes, en fin. El que fue Presidente del Tribunal Constitucional, F. Tomás y Valiente - asesinado por los terroristas-, se lamentaba de esta influencia: «Puedo decir que en los 12 años vividos en el Tribunal Constitucional nunca me sentí presionado por ninguno de los poderes del Estado, pero sí con cierta frecuencia por unos u otros medios de comunicación social» ${ }^{30}$. Hoy en día los jueces están en el punto de mira de estos medios, en los cuales, a su vez, opinan los políticos, los sindicalistas, cualquier pseudointelectual que sepa juntar palabras. Todos

29 GARCía de EnTERría, op. cit., p. 50.

${ }^{30}$ F. Tomás y Valiente, «Sobre la independencia judicial», El País, 30-4-1993, p. 15. 
los días nos desayunamos con artículos de prensa en los que cada uno opina sobre el funcionamiento de la justicia, sobre la actitud de los jueces. Se opina sobre cómo se han de dictar sentencias que afectan a políticos o sindicalistas. Se le dice al Tribunal cómo debe actuar; incluso los políticos declaran sobre la independencia o no de los jueces. Así se dice: «La Sala de lo Penal está dando pruebas de presunta parcialidad» ${ }^{31}$, «ELA rechaza el juicio y pide un fallo absolutorio» ${ }^{32}$, «El político X se querella contra el Juez $\mathrm{Y}^{33}$. Los ejemplos se dan por miles y responden - actitud que no cuestionamos en el fondo, sino que constatamos- al principio de libertad de expresión, cuyo derecho no puede conculcar otro, también fundamental.

Para ayudar más a la presión sobre los jueces, los sindicatos, como poder fáctico, echan más leña al fuego para que la cocción se haga conforme a sus deseos no sólo como representantes de los intereses de sus afiliados y de los trabajadores en general, sino que «apetecen» influir en la política, en los Parlamentos, en la justicia. Los sindicatos pretenden «arrinconar» al Gobierno con intenciones de gobernar, pretenden presionar al poder legislativo con la intención de legislar y acuden a la presión psicológica sobre los jueces para vulnerar su independencia y que se dicten resoluciones arbitrarias y que benefician a sus afiliados. Cuando esto ocurre se produce «una actuación visceral y soreliana, olvidando los sindicatos que son poder, pero también son entidades dentro de una gran comunidad social que históricamente se encuentra en un Estado Social y Democrático» ${ }^{34}$. El sindicato aparece, desde su proclamación en la Carta Magna, hasta en la más elemental de las representaciones laborales o administrativas, pasando por la legitimación procesal en las leyes. Los sindicatos son, al fin, un poder con una esfera y encuadre propios pero sin intervención en los clásicos. Si quieren participar en ellos hay otros métodos — quizás otros sistemas políticos- a través de los derechos reconocidos en la Constitución y las Leyes. No se entiende muy bien que teniendo un foro propio para expresar sus opiniones, dictámenes sobre leyes, etc., cual es el Consejo Económico y Social, se tengan diariamente en los medios de comunicación las expresiones críticas de los sindicatos sobre la actuación gubernamental o judicial.

Otra influencia sociológica que ha tenido y tiene no poca influencia en la elaboración de las normas es lo que en otra ocasión hemos llamado

\footnotetext{
31 El Mundo, 1-10-1997, p. 20.

32 El Mundo, 2-10-97.

33 ABC, 16-2-93, p. 30.

34 Isidoro Alvarez SACRISTÁn, «El poder sindical», Diario de León, 17-12-1988.
} 
«el quinto poder», o la calle, las manifestaciones, la presión de las banderas y de las consignas políticas — para a su vez influir en otras políticas - o las descalificaciones, el poder asambleario que ejerce presión en las fábricas, en la negociación de convenios, que se coloca enfrente de una Audiencia el día de un juicio determinado. Que acude en masa a los juicios laborales para presionar a testigos o peritos - $i$ acaso a los jueces? - y que como quinto poder ${ }^{35}$ toma la calle. «Es un poder no constitucionalizado, pero admitido hasta un determinado nivel de agresión» ${ }^{36}$. «Estas manifestaciones de minorías en las calles provocan incidentes y coartan la libertad de los demás, siembran el terror ciudadano. La autoridad - el poder ejecutivo- no puede intervenir; los jueces - el poder judicial — no actúan por falta de pruebas o denuncias; el poder legislativo está lejos. El cuarto poder se divide. Y nos encontramos que un grupo de presión callejera, de hecho, pero sin el apoyo de la mayoría, queda convertido en poder, arranca acciones de los otros poderes. Ha aparecido el quinto poder $»^{37}$. Una influencia sociológica más añadida a la caldera presionable de la justicia. A veces, la violencia callejera está organizada o nos encontramos con apologetas de conductas delictivas que no son tenidas en cuenta por los jueces, y con que la misma sociedad les acusa de ineficaces o les recuerda su misión, como lo afirmaba el Presidente del TSJ del País Vasco: «los ciudadanos han recordado a los jueces que extremen su celo» ${ }^{38}$.

La presión sociológica existe a través de opiniones de los partidos, los sindicatos, la calle, la prensa, etc., en unos lugares más que en otros. Así, tal fue la presión e incomodamiento de los Jueces en el País Vasco que llevó al Parlamento Vasco a aprobar una proposición no de ley de apoyo a la labor de los profesionales de la Administración de Justicia en la Comunidad Autónoma del País Vasco, cuyo texto fue el siguiente:

«El Parlamento Vasco acuerda expresar: 1. Su reconocimiento a la labor realizada por los profesionales de la Administración de Justicia en nuestra Comunidad Autónoma y a la contribución que desde su dedicación y solvencia profesional realizan por la consecución de la paz social y del progreso democrático. 2. Su respaldo a esta institución básica, a los Jueces, Magistrados, Fiscales y funcionarios y a todo el personal

35 Mansilla, «El quinto Poder», La Hora Leonesa, 26-11-1980, p. 12.

36 Idem.

${ }^{37}$ Idem.

38 Declaraciones en El Correo el 25-8-1997, con respecto a la violencia organizada en el País Vasco. 
que realiza su trabajo profesional al servicio de la Administración de Justicia del País Vasco, al tiempo que expresa nuestro deseo de que sigan realizando su función con independencia y eficacia máxima en Defensa del Estado de Derecho y de la convivencia libre de todos los vascos.»

Hemos subrayado la palabra independencia porque si ésta no se hubiera conculcado no se hubiera producido aquella declaración del Parlamento.

Otras veces la influencia procede de los mismos jueces organizados que solicitan derecho de huelga, cuya actividad se desboca contra la misma independencia judicial, a la que quieren someter a una presión política, pues, como se ha dicho, tal pretensión es una tendencia cuasipolítica $^{39}$. El Derecho de Huelga reconocido en la Constitución va unido al derecho de sindicación, que es incompatible con la condición de Juez. Pues los jueces dictan sus sentencias «en nombre del Rey» y con una actividad emanada del pueblo. Estos poderes plenipotenciarios evitan la retorsión de la reivindicación personal a través del cese del trabajo. La defensa de los intereses profesionales de los jueces que se contiene en el artículo 401.2 de la LOPJ, evita cualquier connotación con los partidos políticos o con los sindicatos, pues tales reivindicaciones, que se pueden llevar a cabo «en todos sus aspectos», deben evitar - mejor está prohibida - la vinculación con los sindicatos y los partidos. Más clara no puede ser la ley. Los intereses sindicales se defienden, en última instancia, a través de una presión histórica que es la huelga; los profesionales de los jueces deben estar presididos por la sensatez de las publicaciones, los dictámenes, las reuniones, las advertencias, etc. La huelga por definición es una presión conflictiva ante una empresa o ante el poder económico. Los Jueces, por su posición en la Corona, no pueden arrogarse un cese en el trabajo al socaire de intereses ajenos a los jurisdiccionales o asociativos. Si los jueces administran la Justicia en nombre del pueblo no pueden desligarse de ese nombramiento en ningún momento de su actividad jurisdiccional. Y si la huelga no es una actividad nacida del derecho, es una acción exógena al mismo juez y, por ende, al pueblo del cual emana la acción judicial. No se puede dejar de «administrar justicia», si se recibe el mandato de hacerlo. El cese - la huelga - del trabajo se sitúa así en una actividad no permitida por el pueblo (ni, por supuesto, por el Rey). Ha dicho el Tribunal Constitucional (sentencia de 8 de abril de 1981) que «el derecho

39 SÁnchez Pego, Boletín de JD, junio 1997, p. 8. 
constitucional de huelga se concede para que sus titulares puedan desligarse temporalmente de sus obligaciones jurídico-contractuales». La pregunta llega enseguida: cuando un Juez se sitúa en huelga ¿de quién se desliga? ¿De su propio Poder Judicial, del que forma parte? ¿Es una huelga contra sí mismo? ¿Se desliga en esos momentos del pueblo o del Rey? ¿Se desliga de los operadores jurídicos, de los abogados, de los procuradores, de los graduados sociales?, ¿se desliga del Ministerio de Justicia, del que recibe sus emolumentos? Y si, llegado el caso, se necesita un arbitraje, ¿quién es el llamado a ser árbitro de los jueces? Si el Juez goza de autonomía e independencia, ¿puede, acaso, situarse en lock-out? La situación es tan inverosímil que llevaría a una pérdida constante de tiempo, y mientras los justiciables esperan que los jueces cesen en su actitud de ocio, se acrecienta la irresponsabilidad de una misión que no es la suya. En cualquier caso, las huelgas de este contenido político, pueden llamarse - para emplear una expresión del Código Civil - de condiciones imposibles, que salen de la esfera del Derecho para entrar en el mundo de la sociología conflictiva de la política, que, por supuesto, nada tiene que ver con la actuación judicial.

\section{La independencia orgánica}

Si atendiéramos únicamente a lo que proclama el artículo 12 de la LOPJ, los Jueces son independientes «respecto a todos los órganos judiciales y de Gobierno del Poder Judicial». Tal independencia supone: 1) Que los jueces o Tribunales no pueden corregir a los inferiores jerárquicos $^{40}$ la aplicación u ordenación del ordenamiento jurídico sino cuando administren justicia en virtud de los recursos establecidos; 2) que no pueden dictar instrucciones sobre la aplicación e interpretación del ordenamiento jurídico hecha por el Consejo del Poder Judicial a sus inferiores.

Por lo que respecta a la independencia entre los órganos y jueces, lleva aparejado que no es posible la unidad de actuación, ni siquiera dogmática o procedimental entre unos y otros. No hay, en este sentido, ni siquiera jerarquía intelectual. No obstante, se produce dependencia, aunque sea jurisprudencial, sobre la actuación de los jueces inferiores, respecto de los superiores del Tribunal Supremo. La paradoja es evidente; mientras el juez de instancia —inferior - es nombrado a través

40 Sobre la expresión inferiores, ver la crítica que de ello expone MONTERo Aroca en Independencia y responsabilidad del Juez, Civitas, Madrid, 1990, p. 75. 
de la carrera, de la oposición o concurso, el Magistrado del Tribunal Supremo es nombrado por el Consejo General del Poder Judicial, cuya composición depende, a su vez, de la composición política de las Cortes. La contaminación se prolonga y la «ciencia jurídica» se proyecta sobre los inferiores a través de la jurisprudencia que «interpreta y aplica la ley» (art. 1.6 CC). La jerarquía orgánica se convierte en jerarquía intelectual. Se debe seguir la doctrina que emite el TS cuando se resuelven recursos, en los cuales puede «corregir» la aplicación o interpretación del ordenamiento jurídico. Estos, si siguen otra doctrina distinta a la del TS — a sabiendas como resolución injusta - están sometidos a la penalidad del artículo 446 del CP, como prevaricación.

La imposibilidad de dictar instrucciones de carácter general sobre la aplicación o interpretación del ordenamiento jurídico imposibilita y ata de manos las posibles sugerencias que, en orden al mejor funcionamiento de la jurisdicción, pudieran dar los Tribunales Superiores de Justicia en aspectos procedimentales para la agilización o eficacia de la aplicación de las normas procesales. Si, como en algunas comunidades ha ocurrido, se redactan formularios para la eficacia informática, no pueden darse normas sobre su interpretación o uso, porque ello puede perturbar la independencia judicial. Si se aprecia que en las notificaciones o las elevaciones de recursos a órganos superiores no se cumplen las normas procesales y el retraso es evidente, no se pueden «corregir» tales actuaciones porque se atenta contra la interpretación procesal que afecta al juzgado. Independencia no quiere decir ineficacia. Si bien es cierto que en el artículo 417.9 de la LOPJ se contempla como falta muy grave el retraso o la desatención de las competencias judiciales, no lo es menos que no se trata de llegar a una ineficacia total sino a situaciones por ignorancia, desconocimiento o interpretación unitaria, que no es lo mismo que conculcar la independencia del Juez. Este, desde que termina sus prácticas en la carrera, no tiene ninguna relación con los órganos judiciales si no es a través de sus propias resoluciones o de las que dictan en fase de recurso los órganos superiores. A veces los mismos jueces lamentan que no se produzcan esas instrucciones, que, por supuesto, serían eminentemente técnicas.

Las tendencias actuales de situar a los jueces bajo la funcionarización ${ }^{41}$ chocan con el concepto clásico de independencia y nos llevarían a la jerarquización que alentaría una disciplina intelectual cerca del totalitarismo jurisdiccional.

41 Ver Deliberación, Revista de la APM, en su número de junio de 1997, página X, que comenta la alusión a tal concepto por un vocal del CGPJ. 
Bien es cierto que los Jueces y Magistrados forman un cuerpo único (art. 122.1 CE), pero como integrantes del «Poder Judicial», distinto del «Personal al servicio de la Administración de Justicia», y que los distingue de una manera clara la Constitución, y de manera más diáfana la LOPJ al distinguir entre Jueces y Magistrados y a los «Cuerpos de Funcionarios». El hecho de que ejerzan funciones jurisdiccionales no quiere decir que sean funcionarios stricto sensu. El servicio al Estado se puede cumplir a través de varias formas: instituciones, Administración Pública, representativa o judiciales. Y dentro de este último como funcionario (dentro del Poder ejecutivo) o como Juez o Magistrado (Poder Judicial). El funcionario puede bocetar o sugerir, el Juez tiene la misión sacralizada del «arte de Juzgar»(*). El Juez, por decirlo con expresión de Platón ${ }^{42}$, debe «olvidarse de sus propias conveniencias». El Juez no es funcionario en el sentido administrativo del término, entre otras cosas porque se le debe alejar del concepto arcaico del reloj, manguito y covachuela. Al Juez le está prohibido el «venga usted mañana». La misión es única, independiente de jerarquía y bajo la divisa de la honestidad profesional. Si bien la autonomía judicial se aleja de la jerarquización funcionaria, debe responder — como razona Montero Aroca $^{43}$ - «a una concepción política de no superioridad de un poder sobre otro, sino de igualación dentro del marco de actuación de cada uno de ellos señalado constitucionalmente». La justeza de las resoluciones viene enmarcada por lo que diga el órgano judicial competente, lo que nos lleva de la mano a las garantías del justiciable de acceder a un juez cuyo status no se puede prejuzgar y cuya causa deber ser oída «por un Tribunal independiente e imparcial, independencia e imparcialidad que no requieren, para entenderse vulneradas, la producción de una resolución positivamente parcial o positivamente carente de independencia. Es suficiente, por el contrario, que el status jurídico del juzgador no reúna las condiciones que en sí mismo y como tal status vienen exigidos por el artículo 24.2 CE, para que pueda entenderse producida una vulneración actual, inmediata y directa del derecho fundamental» (S TC 11 de julio de 1994). Las resoluciones que dicte un juez incompetente, además de vulnerar la tutela judicial efectiva, resultan ineficaces. Lo mismo se diría si un órgano «superior» anulara una resolución ante un recurso - o de oficio- en los supuestos legales,

(*) Título de una publicación de Carlos M.a Entrena Klett, La equidad y el arte de juzgar, Aranzadi, Pamplona, 1979.

42 Cit., Cicerón, Los oficios, Austral, Madrid, 1980, p. 57.

43 Montero Aroca, op. cit., p. 123. 
y nuevamente el órgano así advertido volviera a recaer en el mismo defecto procesal o sustantivo del que le advirtió quien resolvió el recurso o quien advirtió para que se subsanase un defecto de orden público jurídico. Quien predeterminó la Ley y resolvió la contienda no puede ser desoído, so pena de responsabilidad disciplinaria o penal.

La independencia orgánica así entendida no puede por menos de verse acechada por la parcialidad de la dependencia del mismo Poder Judicial, cuyos miembros son elegidos por los partidos políticos, en el Senado y en el Congreso. A nuestro entender, la LOPJ de 1985 desarrolló el artículo 122.3 de la CE sin atender ni a su espítitu ni a su letra. Veamos. El nombramiento de los miembros del Poder Judicial — veinte- lo decidía sobre $8-4$ el Senado y 4 el Congreso- entre abogados y juristas de reconocida competencia y con más de 15 años de ejercicio profesional. Los otros doce miembros los dejaba para que fueran nombrados «en los términos que la Ley establezca». De manera que si la Constitución hubiera querido que fueran nombrados por el Senado o por el Congreso, los habría incluido en ese sistema. Al dejar su nombramiento entre Jueces y Magistrados por otro método distinto al anterior no permitió someterlos a los vaivenes de los partidos políticos. El nombramiento era así coherente con la prohibición de afiliación de los jueces a sindicato o partido político alguno. Pero una malhadada propuesta cuando se descutía la LOPJ de 1985 vino a introducir un nombramiento distorsionador en el órgano de Gobierno del Poder Judicial, al decir la LOPJ (art. 112.3) que cada una de las Cámaras propondrá a los otros seis vocales entre Jueces y Magistrados. Así se tergiversaba la norma constitucional infringiendo el principio general del Derecho ubi lex non distinguit, nec nos distinguere debemus, porque la dicción de la Ley Orgánica no es lo que mandó la Constitución, al distinguir —en aquellalos nombramientos por las Cámaras y por otros distintos. Si con la interpretación literal de la CE el Poder Judicial tenía cierta influencia del Poder Legislativo ( 8 de sus miembros), con la redacción que se dio en 1985 a la LOPJ la vinculación a aquel es total. Así da casi vergüenza leer en la prensa que tal o cual Vocal del Consejo ha sido nombrado a propuesta del partido X o de la coalición política Y. Es un remoquete que le queda al vocal para todo su mandato, sin que pueda desligarse de sus actuaciones bajo los apellidos de progresista o conservador, o de izquierdas o de derechas. La dependencia está servida, la independencia conculcada. A veces esta dependencia se ha vestido con el ropaje «de los mecanismos democrático-representativos» ${ }^{44}$, lo que evidencia

44 Perfecto ANDrÉs IbÁÑEZ, Justicia/Conflicto, op. cit., p. 44. 
la frase socialista de que «Montesquieu ha muerto». Aquella máxima de Charles de Secondant de que «el poder debe frenar el poder» queda relegada con la intersección de los tres poderes del Estado. Lo que llevó a preguntarse a Bentham ¿qué garantía de libertad puede haber en la separación de poderes si los tres están controlados por el mismo grupo o clase ${ }^{45}$.

\section{La independencia extrajudicial}

Lo que podemos llamar influencia extrajudicial puede perturbar la independencia judicial, aunque se realice, en la práctica, a través de situaciones derivadas de la vida familiar, de la propia actividad de la Administración, de la funcionalidad de otras instituciones, etc. Por ello hemos de dividirlas y analizarlas.

a) Personas públicas y privadas. Bajo la expresión de que «todos están obligados a respetar la independencia de los Jueces y Magistrados», el artículo 13 de la LOPJ amplía la prerrogativa a cuantos tengan relación -o la provoquen- con la justicia. La tutela de este precepto permite la actividad de: 1) Los propios jueces, que, ante tal situación, deben seguir el camino orgánico, poniéndolo en conocimiento del Consejo del Poder Judicial y, además, dar cuenta de los hechos al Juez o Tribunal competente, y pueden, además, «practicar las diligencias indispensables para asegurar la acción de la justicia y restaurar el orden jurídico» (art. 141 LOPJ); 2) el Ministerio Fiscal, que «debe velar por la independencia de los Tribunales» (art. 124.1 CE), que, como mandato constitucional, debe por sí o a petición de los Jueces «promover las acciones pertinentes» (art. 14.2 LOPJ)

Por otra parte, la responsabilidad de la independencia se traslada, —bajo el término todos- a las personas privadas, que están obligadas a prestar la colaboración necesaria para la ejecución de las resoluciones judiciales (art. 17.1 LOPJ), cumpliendo las sentencias que hayan ganado firmeza. Lo mismo hay que decir, y con mayor fuerza, si cabe, de las Administraciones Públicas y los funcionarios, que respetarán las resoluciones judiciales ${ }^{46}$.

b) Las incompatibilidades. Como mandato del artículo 127.2 de la CE, el régimen de incompatibilidades debe asegurar la total independencia de

\footnotetext{
45 Enciclopedia Internacional de las Ciencias Sociales, tomo 7. Madrid, 1974, p. 214.

46 Véase los artículos 463 y siguientes del CP, en los delitos «De la obstrucción a la Justicia».
} 
los Jueces y Magistrados, para que tal aseguramiento sea eficaz. Una incompatibilidad en el ejercicio profesional cuyo régimen se declara «altamente riguroso» ${ }^{47}$, y cuyo cuadro, además de las circunstancias referentes a los partidos políticos, sindicatos u otros cargos públicos, se contiene en un cuadro de incompatibilidades y prohibiciones en los artículos 389 y siguientes de la LOPJ. Desde la perspectiva de la Ley, esta incompatibilidad se extiende a los siguientes ámbitos: 1) Político. No pueden pertenecer a partido político alguno ni en las actividades que exijan participación activa en los mismos, ni «tener empleo» a sus servicios (art. 395 LOPJ). Tal desconexión con la actividad de los partidos se enmarca en la posible contaminación que respecto del ejercicio jurisdiccional pudiera dedicar el Juez o Magistrado un uso del Derecho que se concitara con los estatutos o tendencias del partido. Bien es cierto que la ideología cercana a sus quehaceres puede influir en la impronta de las decisiones. Pero, al menos, no se verá vinculado por mandato relacional. 2) Sindical. No pueden pertenecer a sindicato alguno, aunque sí pueden pertenecer a asociaciones profesionales, en cuya actividad se prohíbe (art. 401.2 LOPJ) la vinculación a sindicatos. Extraña que en ocasiones algún sindicato relacione su actividad con determinada asociación profesional. Como ya dijimos más arriba, si bien los intereses sindicales defienden a los trabajadores sobre lo que «les son propios» (art. $7 \mathrm{CE}$ ), en nada empaña la constitución de una asociación para acceder a la defensa de los intereses profesionales de los jueces. Por esta vía la defensa está asegurada sin necesidad de someterse a los vaivenes o las decisiones de un sindicato, cuya dirección es exógena a la actividad jurídica. 3) Administración. No puede tener cargo alguno en la Administración, ni en otros Poderes del Estado, sea por elección o por designación, ni tomar parte en las elecciones legislativas o locales, aunque pueden tomar parte en las mismas en ejercicio de su misión (por ejemplo formar parte de las Juntas Electorales). 4) Profesional. No pueden desarrollar actividad profesional distinta de la de Juez o Magistrado, ni profesión libre ni dependiente. No pueden ejercer la abogacía o la Procuraduría, ni asesoramiento jurídico sea o no retribuido. No pueden ejercer actividad mercantil, ni ejercer en empresas mercantiles cargos de Gerente, Director, Administrador, Consejero, sean sociedades públicas o privadas. 5) Otras actividades. No pueden dirigir escritos a los poderes, autoridades o funcionarios públicos, felicitaciones o censuras por sus actos, ni asistir a actos o reuniones que no tengan carácter judicial.

47 Oscar Alzaga, op. cit., p. 769. 
6) Familiar. No pueden los Jueces o Magistrados actuar en los casos con vinculación familiar, ni formar Sala en los mismos dando lugar a los supuestos de abstención y recusación a que se refieren los artículos 219 y 391 de la LOPJ.

c) Las compatibilidades. Tal relación de incompatibilidades, que se exigen para que la decisión del juzgador no se vea empañada por directrices ajenas, influencias psicológicas o morales, compromisos ideológicos o materiales, como se ve, es amplia. Unicamente es posible compatibilidad del cargo con: 1) Docencia; normalmente en centros universitarios - públicos o privados- para la enseñanza en la rama del Derecho, siempre que sea en régimen de tiempo parcial y con duración determinada ${ }^{48}$ que se desarrolle a partir de las quince horas y que no afecte a los deberes de residencia, asistencia al trabajo y al cumplimiento estricto de los deberes. 2) Investigación jurídica; que puede desarrollarse como una actividad extrajudicial, pero siempre que no menoscabe o comprometa la imparcialidad o independencia judicial. Es cierto que la actividad publicista — como producto de una acción investigadora- puede dar origen a críticas sobre el funcionamiento de la Justicia, de los otros Poderes o de la Administración, pero ello no menoscaba per se la imparcialidad de quien juzga y a la vez investiga o publica artículos en revistas especializadas o en prensa periódica. Pueden ser autorizadas por el CGPJ compatibilidades para actividades de investigación no permanentes o de asesoramiento en casos singulares, cuando se trate de un concurso público o se requiera una especial cualificación en el ámbito de la Ley 53/1984, de 26 de diciembre, de incompatibilidades. 3) Producción o creación literaria o artística, científica o técnica, que se desarrolle fuera de las horas de audiencia para la confección de libros jurídicos o no, expresiones de pintura o grabado, etc. 4) Otras compatibilidades. Las que se derivan del artículo 19 de la Ley 53/1984, entre las que destacan la administración del patrimonio personal (sin pertenecer a los cargos del art. 389.8 de la LOPJ), la dirección de Seminarios o dictado de conferencias, la participación en Tribunales calificadores de pruebas selectivas, participación en exámenes, evaluaciones, miembros de las Juntas rectoras de la Mutualidad Judicial o la asistencia ocasional en coloquios y programas de cualquier medio de comunicación social.

d) La independencia económica. Como integrantes de uno de los Poderes del Estado, los Jueces y Magistrados perciben sus emolumentos con cargo a aquel, sin que sea posible su remuneración a través de tasas

48 Ver Reglamento 1/1995, de 7 de junio, de la Carrera Judicial. 
o abono por parte de los justiciables. Lo que dice el artículo 402 LOPJ es que el Estado, a través de los Presupuestos del Estado, garantiza - $\mathrm{O}$ debe garantizar - la independencia económica. Esta garantía pasa por los siguientes parámetros: a) Ser adecuada a la dignidad de la función jurisdiccional. Tal cuestión legal tiene necesariamente una impronta comparativa, pues si bien todos los servidores del Estado tienen una digna función, la actividad de cada uno de ellos responde a misiones - aunque sean importantes - que entran en una dinámica de preferencia. En todo caso, una sociedad puede convivir sin determinados servicios, pero sería imposible la más mínima convivencia sin el ejercicio de la Justicia, pues no estamos ante aquella ciudad utópica de Campanella ${ }^{49}$ en que «las Leyes son poquísimas» y cuya pena impuesta por los jueces se limitaba a «leer» el «pecado» y se penaba «con gran suavidad». Nos encontramos en una sociedad en que «el arte de juzgar» debe estar alejado, como de la peste, de la influencia económica o de la prebenda material. Y sólo se alcanza la independencia si a la dignidad del juzgador la adornan las virtudes personales, los honores sociales, las inmunidades judiciales, y la acompañan las remuneraciones económicas que lo alejen de la tentación de cohecho o la prevaricación. b) Esta garantía económica se extiende a las prestaciones de la Seguridad Social a él y su familiar, tanto en activo como en la jubilación. c) Si, como se contiene en el artículo 403 de la LOPJ, las retribuciones de los jueces deben tener en cuenta la plena dedicación — dada la incompatibilidad que hemos visto más arriba - y el tiempo de servicios, hemos de decir que al Juez o Magistrado no se le exige horario porque las decisiones judiciales no pueden estar sometidas a tiempo de reloj, ni a horario de oficina. Es común que entre los jueces eficaces las decisiones más importantes se tomen, normalmente, en tiempo en que el resto de los funcionarios se dedican al ocio. Las labores de «dedicación» que se realizan en los juzgados en horas de audiencia impiden, por el tráfago de los juicios, las pruebas, las firmas, las lecturas, etc., la serena actitud de dictar una sentencia. Por eso, la expresión de la Ley «tiempo de servicios» no tiene otro significado que constatar que los jueces no tienen para sí horario de trabajo, ni ocios de puentes, ni fines de semana. Su labor es constante y en exclusiva. Ello lleva aparejada la posible retribución sobre «el cargo», «la categoría» o «el puesto de trabajo». La intención de remuneraciones sobre productividad es de muy difícil consecución. Así como el número de resoluciones puede ser fácilmente comparable

49 Tomás Campanella, La ciudad del sol, Mondadori, Madrid, 1988, p. 146. 
o medible, la calidad o eficacia de otras no puede llevarse al mundo de los números ${ }^{50}$.

\section{La responsabilidad}

La independencia a que nos venimos refiriendo tiene otras contrapartidas personales de las que no se pueden escapar los Jueces y Magistrados: una de ellas es la responsabilidad, tal como se dice en el artículo 117.1 CE. La «respuesta» de sus actos ante terceros lo es en «el ejercicio» o «el desempeño de sus funciones» en los ámbitos penal, civil o disciplinario, desde el punto de vista profesional. Pero hay otra responsabilidad personal e interna que se desarrolla en el ámbito ético o moral que responde a otros valores menos legalistas — aunque a veces proceda de ellos- y que invaden la conducta de cada aplicador del Derecho y la Justicia. Hemos de dividir el análisis, por lo tanto, en dos bloques: responsabilidad ético-profesional y responsabilidad jurídico-profesional.

A) Desde la perspectiva ético-profesional podemos comenzar por la que adquieren nuestros jueces al jurar o prometer la Constitución, que se regula en el artículo 318 de la LOPJ, bajo la siguiente fórmula: «Juro (o prometo) guardar y hacer guardar fielmente y en todo tiempo la Constitución y el resto del ordenamiento jurídico, lealtad a la Corona, administrar recta e imparcialmente justicia y cumplir mis deberes judiciales frente a todos».

Tal compromiso obliga a un cumplimiento exacto de todo el complejo mandamiento constitucional, que si en el artículo $9 \mathrm{CE}$ ordena la sujeción de los ciudadanos y los poderes públicos a la Constitución y al resto del ordenamiento jurídico, con más motivo a los Jueces que, además, hacen juramento (ante Dios) o prometen (por su honor) un acatamiento y hacer acatar al resto de los ciudadanos «en todo tiempo» (mientras esté vigente y mientras se sea «poder judicial»). Obliga a administrar justicia, no sólo desde la perspectiva obligacional de su condición profesional — dictar resoluciones - sino llevar a la sociedad el sentido de la rectitud (administración recta) y de la imparcialidad, esto es, que se sitúe como profesional en la predeterminación que la ley ha hecho de su labor, en su ámbito y territorio, y como ejercicio en el

\footnotetext{
50 En el Libro Blanco de la Justicia de 1997 se incorporan unos módulos de cargas de trabajo para los órganos Unipersonales y Colegiados que responden al número de Resoluciones máximas al año por cada uno de ellos teniendo en cuenta los rendimientos máximos, medios y mínimos de los órganos. Los peligros pueden llevar a aumentar la cantidad en detrimento de la calidad. Pero no cabe duda de que algún sistema de medición de trabajo debe haber.
} 
fiel de la balanza que representa (como apuntaba de una manera gráfiea Kafka, «la justicia debe estar inmóvil, pues de lo contrario la balanza oscila y no puede pesar con exactitud») ${ }^{51}$.

Estamos ante la imparcialidad subjetiva en el desempeño de su labor, alejado de los vaivenes extrajudiciales y en conexión directa con la independencia.

Otro aspecto que exige un comportamiento ético $-\mathrm{o}$ de deontología profesional- es la formación y el conocimiento constante que ni esté erosionado por la pseudointelectualidad ni adocenado por la uniformidad ex libris. La difícil formación del Juez pasa por la idea dorsina de la laboriosidad al servicio de la inteligencia y ser intelectuales, a través, qué duda cabe, de un sacrificio que para D'Ors era ni más ni menos que nobleza ${ }^{52}$. El principio general del Derecho iura novit $\mathrm{cu}$ ria cobra aquí plena aplicación; pues la verdadera traducción es que los Tribunales conocen el Derecho, aunque en su aplicación procesal derive en la facultad de los jueces de aplicar las normas conforme a su conocimiento sin la vinculación a las propuestas de las partes. Tampoco hay que interpretar la obligación del conocimiento y el reciclaje en el sentido global y amplio, cuya tarea es, por total, inalcanzable para el saber humano, sino que la aprehensión de conocimientos responde a la constante y permanente formación jurídica, acompañada por la defensa de la justicia, pues si — como decía Cicerón- la ley es el Magistrado silencioso, el magistrado es la ley parlante. La formación permanente es una de las funciones de la Escuela Judicial a través de cursos, seminarios, investigaciones, etc. Pero hay otra formación que se incardina en la labor diaria y personal y que responde a la noble tarea de hacer justicia a través de la norma pero bajo los auspicios de la ética.

La laboriosidad del juzgador se entroniza en su aspecto personal -ético- profesional, olvidando la indolencia para velar por la eficacia y la atención al justiciable. Algunas veces se ha criticado la eficacia de un juzgado - al día de sus asuntos - y el retraso de otro que, pared con pared, tiene los mismos funcionarios y el reparto de los mismos expedientes. Aparte factores procesales, no cabe duda de que se ve la mano de un juez eficaz y resolutorio. Pero tampoco es bueno que el juez se pliegue a la burocratización de los números ${ }^{53}$, pues, cuando se

51 Franz KAFKA, El proceso, Edaf, Madrid, 1989, p. 222.

52 Eugenio D’Ors, Antología, Doncel, Madrid, 1960, p. 103.

53 El Libro Blanco de la Justicia de 1997 establecía carga de trabajo según sean los órganos unipersonales o Colegiados. Por ejemplo, juzgados civiles 850 asuntos, Salas de TSJ, 350, Audiencias, 400, etc. Responde, según el libro, a mediciones de rendimiento, de acuerdo con la carga de trabajo que pueden soportar los órganos jurisdiccionales. 
descubre en el Juez español «un fuerte componente burocrático» ${ }^{54} \mathrm{y}$ «realiza escasas incursiones en el campo de la tutela de los intereses difusos» ${ }^{55}$.

Otros valores, como diría Martinez Calcerrada ${ }^{56}$, podrían referirse a la intelectualidad, la vocación o el factor psíquico. No es momento de advertir sobre las situaciones psíquicas, pero sí relacionar la vocación en la tarea, porque sin ésta no hay «entrega sin reservas» ${ }^{57}$, no hay posibilidad de formación continua, no existe el sacrificio, la investigación en la labor, la impronta — desde el acceso al escalafón- de que la misión de un juez es clave en la vida social, que sólo es posible el Estado democrático y social de Derecho, si la rectitud de la justicia impera a través de ganar todos los días la batalla a la injusticia y la indolencia. La vocación tiene que estar alejada de las nimiedades de la burocracia - a pesar de que la máquina judicial sea «escasa en medios y víctima desde 1985 de una legislación deplorable» ${ }^{58}$-, de las inseguridades de la política, de la crítica de los medios de comunicación, de las iniquidades de los compañeros. Por eso, se dice que la vocación es sacrificio. Ante tales presiones el Juez debe permanecer impávido, desoyendo los cantos de sirenas que, por un lado o por otro, siempre se oirán ${ }^{59}$. El Juez está al servicio del Estado «frente a todos» — como juró o prometió- y bajo el mandato que recibió del pueblo organizado. Esta actividad, que no es nueva, pues ya Lucrecio ${ }^{60}$ lo predijo: «Eligieron de entre ellos Magistrados, que obedecieron voluntariamente», es un enlace entre la fuente de que emana el poder (pueblo) y la actitud vocacional

54 Abdón Díaz SuÁREz, «Los jueces ante la crisis de la Justicia». Revista General de Derecho, n. ${ }^{\circ}$ 523-1988, Valencia, p. 1.669.

55 Ibidem.

${ }^{56}$ Luis Martínez Calcerrada, «Juez y Justicia independientes», Diario $A B C$, 13-11993.

57 Martínez Calcerrada, op. cit., p. 1.

58 José Luis Manzanares SAmaniego, «Administración de Justicia y Poder Judicial». Diario $A B C, 12-10-1997$, p. 56.

59 Extrañan las Resoluciones — como en la que se pone en entredicho la imparcialidad del Juez natural en el «caso Sogecable» y se le aparta del asunto- bajo la apariencia de «quedar en entredicho la imparcialidad del juez». Por este camino cualquiera puede difundir diatribas contra un Juez con el objeto de apartarle del conocimiento de un asunto. Así puede peligrar la imparcialidad y erosionarse la vocación.

60 Tito Lucrecio, De la naturaleza de las cosas. Cátedra, Madrid, 1994, p. 339. «Eligieron de entre ellos Magistrados / que obedecieron voluntariamente: / porque el género humano, fatigado / de vivir en dura servidumbre, / y con enemistades extenuado, /más de su agrado recibió las leyes / y los justos derechos: pero como / el enojo llevase la venganza / mucho más lejos de lo que las leyes / permiten al presente, se cansaron / de la anarquía y las venganzas fieras. / De aquí nació el temor de los castigos...» 
que debe presidir la logística de su labor. Así, la vocación no tiene otra ligazón que la propia estima, la deontología profesional, el sacrificio de la labor, el servicio a lo intelectual, en suma. Con tal misión es imposible que esté relacionado con otras dependencias. Para ellos, si impera la vocación se arrumban otras irresponsabilidades.

En otra ocasión ya hemos dicho ${ }^{61}$ que «es verdad que hay - puede haber-varios tipos de jueces, algunos con el marchamo de intocable, que llevan el concepto independiente al extremo del subjetivismo anacrónico o alejados de la realidad social, cuyas resoluciones asombran a los profesionales, sometidos a la incertidumbre de ganar o perder un pleito según el Juez que lo dirima; pero también —eso es lo deseableacceden Jueces que son la simbiosis entre la sociedad y el pueblo, que protegen los intereses legítimos individuales o colectivos».

Bien es cierto que no hay un código de conducta profesional, ni — como dijo el TS en sentencia de 23 de abril de 1997 (La Ley 5386) se puede imponer a los Tribunales un concreto modus operandi, y «no existen fórmulas magistrales para que se llegue al conocimiento del Juzgador la justicialidad»; el concepto de la sana crítica a que se refiere en algunos artículos la LEC, cobra aquí todo su sentido, como un concepto jurídico indeterminado ligado a la objetividad, la razonabilidad, la honesta actuación, vocacionalidad, en fin.

B) La responsabilidad jurídico-profesional es la que desarrolla la LOPJ en el Título III del Libro IV, en los artículos 405 al 427 (independientemente de la responsabilidad del funcionamiento de la Administración de Justicia a que se refieren los artículos 292 a 297 de la LOPJ). Tal responsabilidad es — como se ha dicho ${ }^{62}$ - un imperativo ejercicio del poder y «un explícito principio de articulación de la Justicia tanto en su vertiente dogmática cuanto en las vertientes administrativas y prestacional».

a) La responsabilidad penal por delitos y faltas cometidos en el «ejercicio de sus funciones» y que se «exigirá» conforme a lo previsto en la LOPJ. Ello no es del todo exacto, pues si bien la LOPJ prevé la actuación de los jueces - lo que deben ser-, el incumplimiento penal está previsto por la LECRIN y el CP, ya que por la DA $1 .^{\circ}$ de la LO 5/1995, de 22 de mayo, se deroga el artículo 410 de la LOPJ que regulaba el denominado «antejuicio» que debería conocer el mismo Tribunal que entienda de la causa abierta contra el Juez. El CP vigente - LO 10/1995,

61 Isidoro Alvarez Sacristán, «La eficacia de la Justicia», El Diario Vasco, San Sebastián, 1-1-1987.

62 Juan F. LÓPez Aguilar, La Justicia y sus problemas en la Constitución. Civitas, Madrid, 1996, p. 55. 
de 23 de noviembre - regula los delitos en los que pueden estar incursos los Jueces y Magistrados: prevaricación (art. 446), revelación de secreto sumarial (art. 460), usurpación de atribuciones (arts. 507 y 509), obstrucción a la justicia (art. 463.3), y en general aquellos delitos o faltas que pudieran aplicarse como cargo público en el ejercicio de sus funciones.

b) La responsabilidad civil $^{62 \mathrm{bis}}$ se exige por los daños y perjuicios causados, con dolo o culpa, en el ejercicio de sus funciones. A la que hay que añadir la «negligencia o ignorancia inexcusable en el ejercicio de sus funciones» a que se refiere el artículo 903 de la LEC $^{63}$.

Lo dicho en el artículo 411 LOPJ es un transunto del artículo 1.902 $\mathrm{CC}$ sobre las obligaciones que nacen de culpa y negligencia y se contraen «sin convenio», como se dice en el Título XVI del Libro IV del CC ${ }^{64}$.

Si bien en algunas circunstancias es difícil delimitar el camino entre la responsabilidad contractual (art. $1.101 \mathrm{CC}$ ) y la extracontractual, dada la naturaleza de las relaciones sociales en el mundo de hoy, el TS ha dejado dicho que «la culpa extracontractual se diferencia de la contractual en que aquella presupone un daño con independencia de cualquier relación jurídica anterior a las partes, fuera del deber genérico y común de todos los hombres del alterum non laedere, mientras que la

62bis «La responsabilidad civil de Jueces y Magistrados — mal llamado recurso- que establecen los artículos 903 y siguientes de la LEC y 16.1 y 411 a 413 de la LOPJ por consecuencia del ejercicio de sus funciones cuando hubieran incurrido en dolo o culpa y asimismo por negligencia o ignorancia inexcusable, no es un derecho abstracto, inalcanzable para los ciudadanos. Al contrario, es del todo conveniente su exigencia y ha de potenciarse pero dentro de los estrictos presupuestos legales y con acatamiento a las condiciones de procedibilidad que la normativa legal establece, a fin de evitar abusos, lo que sería efecto contrario, tan discorde con la justicia, como su indebido y desviado ejercicio; en este sentido la exigencia del artículo 903 LEC se presenta clara e imperativa, en cuanto dispone que necesariamente han de utilizarse en tiempo los recursos legales procedentes, o, en su caso, haber reclamado oportunamente durante el juicio (art. 413 LOPJ). De esta manera se precisa tanto la reclamación correspondiente, lo que exige que sea acorde a la Ley, como que ésta se presente con oportunidad procesal, utilizando los remedios legales previstos.» (S TC 19-29-1994, La Ley 1994-2, 626)

${ }^{63}$ La regulación procesal se contiene en los artículos 903 y siguientes de la vigente -en 1997- LEC.

64 Sobre la numerosa bibliografía reciente, se destacan las diferentes monografías de Ricardo De Angel, Tratado de Responsabilidad Civil, Civitas, Madrid, 1993. M. ${ }^{a}$ Luisa AtienZA, La Responsabilidad Civil del Juez, Tirant lo Blanch, Valencia, 1997. Juan MonTERo Aroca, Responsabilidad Civil del Juez... Tecnos, Madrid, 1988. Responsabilidad Civil, CGPJ. Tomo XIX 1993 (Varios autores). Santiago CAVANILlas e Isabel TAPIA, La concurrencia de responsabilidad civil... Aretes, Madrid, 1992. Mariano YzQuIERdo TosLada, Responsabilidad Civil, Reus, Madrid, 1993. Santiago Cavanillas Múgica, La transformación de la Responsabilidad Civil en la Jurisprudencia, Aranzadi, 1987. 
segunda presupone una relación preexistente que ordinariamente es un contrato» ${ }^{65}$.

Alejados de las teorías que determinaban la relación procesal — con intervención del Juez - como un contrato — felizmente criticada por la doctrina procesalista - y desechadas las teorías sobre la relación pública, la institucional o las mixtas, se sitúa el Juez como tutelador de normas constitucionales y garantistas de valores superiores y que tienen su plasmación pedestre en la pretensión; o como recordó Aragoneses ${ }^{66}$ algo tan obvio como «una institución jurídica para la realización de la justicia... que satisface la pretensión».

Esta responsabilidad, en cuanto al sujeto puede ser pedida por la parte que pueda resultar perjudicada y bajo los siguientes requisitos procesales:

1) La demanda se interpondrá una vez que se ponga fin al proceso, y la sentencia o el auto en que se resuelva el fondo de la fundamentación de la negligencia, dolo o morosidad, sea firme.

2) El plazo de interposición es de 6 meses desde que se dictara el auto o la sentencia que ponga término al pleito o causa (art. 905 LEC).

3) El órgano ante el cual se ha de interponer la demanda es el Tribunal Superior inmediato.

4) En ningún caso la sentencia dictada en juicio de responsabilidad civil alterará la que hubiera ocasionado el agravio. Si no se estima la responsabilidad se imponen las costas al demandante. En el caso de estimarse, se comunican los casos al Fiscal «a fin de que resulten méritos para exigir la responsabilidad criminal, inste y proponga lo que estime procedente» (art. 918 LEC). Este último supuesto es un agravio a los Jueces, ya que se les exige un plus de comportamiento y se lleva al terreno de la penalidad lo que se ha ejercido como responsabilidad extracriminal, pues si bien en la jurisdicción civil vinculan las sentencias penales $-\mathrm{y}$ desde la pena se exige la indemnización civil (art. $116 \mathrm{CP}$ ) - la restitución patrimonial en la responsabilidad civil no nace del delito, sino de los hechos que lo constituyen. Esta culpa aquiliana surge en el momento en que surge el daño o quien se cree dañado por la decisión judicial, sin que previamente exista una obligación con el justiciable que no sea la derivada de la tutela judicial efectiva.

65 Distinción que hace a su vez José María MiQuel GonzÁlez, en La Responsabilidad contractural y extracontractual. CGPJ, Tomo XIX, p. 61.

66 Pedro Aragoneses, Proceso y Derecho Procesal. EDERSA, Madrid, 1997, p. 259. 
c) Responsabilidad disciplinaria. Como cualesquiera otros miembros de colegios, instituciones, funcionarios, etc., los Jueces y Magistrados están sometidos a la disciplina de los órganos superiores del Poder Judicial del que forman parte. Las alusiones que se hagan a este respecto en la LEC deben entenderse derogadas, si se oponen a lo que regula el Capítulo III del Título III del Libro IV de la LOPJ, aunque ya fueron derogados algunos artículos por la Ley 16/1994, de 8 de noviembre, y en especial el artículo 447 LEC sobre la posibilidad de corregir disciplinariamente a los jueces inferiores por el órgano superior. La actual normativa - con evidente vocación de Estatuto de funcionamiento- se regula en los artículos 414 al 427 de la LOPJ, bajo los principios de legalidad y garantía. La primera porque no pueden ser sancionados sino en los supuestos a que se refiere el grado de las faltas (muy graves, graves y leves), y en cuanto a la actuación garantista, a través del expediente incoado al efecto, con audiencia del interesado y el Ministerio Fiscal. 